\title{
ENTREPRENEURIAL COMPETENCES AND \\ ENTREPRENEURIAL PERFORMANCE: EMPIRICAL INSIGHTS OF FEMALE ENTREPRENEURS IN KENYA
}

\author{
Kimeu Muindi \\ Moi University \\ a.m.kimeu@vu.nl \\ Bernard Kibeti Nassiuma \\ Moi University \\ bnassiuma2@gmail.com \\ Enno Masurel \\ Vrije Universiteit Amsterdam \\ e.masurel@vu.nl \\ Kees van Montfort \\ Erasmus University Rotterdam \\ fam.montfort@planet.nl
}

\begin{abstract}
The purpose of this paper is to examine entrepreneurial competences among female entrepreneurs within the context of developed countries which have been greatly neglected in the same context of emerging economies. This empirical research is based on a survey of 301 micro and small enterprises located in Uasin Gishu County, Kenya, run by female entrepreneurs. Its focus is on the following entrepreneurial competences: the need for achievement, locus of control, tolerance of ambiguity, innovativeness, risk-taking propensity, self-efficacy, egoistic passion; goal setting; resilience; trustworthiness; emotional stability; and patience. In measuring entrepreneurial performance, the constructs of firm performance, development of personal wealth, and social performance were used. The findings show that a proper measurement instrument has been applied to check on the constructs of entrepreneurial competences and entrepreneurial performance. The paper makes a finding that entrepreneurial competences do exist among female entrepreneurs in emerging economies. However, it was established that there is hardly any correlation between entrepreneurial competences and entrepreneurial performance. This finding, presents a stimulating area for further research within the contextual framework of emerging economies. The study contributes to the advancement of the literature on entrepreneurial competences and how they relate to the entrepreneurial performance of female entrepreneurs in an emerging economy context.
\end{abstract}

\section{Keywords}

small and micro enterprises; female entrepreneurs; entrepreneurial competences; entrepreneurial performance; firm performance, development of personal wealth; social performance

\section{JEL Classification}

M19

\section{Introduction}

Entrepreneurial competences have been identified as capabilities necessary for the exercise of successful entrepreneurship, and, as such, entrepreneurial competences are often related to the development of small and new businesses (Colombo \& Grilli, 2005). In this article, we undertake an empirical study to determine whether there is an identifiable link between the entrepreneurial competences of the entrepreneur and the entrepreneurial performance of the firm. (Onstenk, 2003) argued that proper 
entrepreneurial competences are a basic condition for an individual to start, operate, and sustain a business within a given marketplace.

Onstenk, (2003) sustained the argument that competent entrepreneurs use knowledge, attitudes, and skills in a manner which allows them to carry out tasks, and solve problems, dilemmas effectively, and contradictions. Interest in entrepreneurial competences can be derived from the supposed link between entrepreneurial competences and the start, survival, and growth of an entrepreneurial venture (Mitchelmore \& Rowley, 2010). There is evidence to suggest that it is necessary to have an understanding of the entrepreneurial competences, and that the changing role of the entrepreneur through the various phases of development of firms which supports the development of entrepreneurial competences, and could, therefore, have an effect on successful firm growth (Nichter \& Goldmark, 2009).

As Cutura, (2006) argues, the critical role of female entrepreneurs in the Kenyan economy and their families' prosperity requires more insight into the development of entrepreneurial competences of these entrepreneurs. Hardly has any research been undertaken into the development of the entrepreneurial competences of female entrepreneurs in this part of the world. Thus, this paper presents our approach to determine whether such entrepreneurial competences could be a positive predictor of entrepreneurial performance. The latter is described in terms of firm performance, development of personal wealth, and social performance.

Therefore, the research question we aim to answer in this paper is: To what extent do entrepreneurial competences contribute to the entrepreneurial performance of female entrepreneurs in Kenya?

Notably, the paper is arranged as follows. In Section 2, we present the theoretical framework, explain the meaning of female entrepreneurship, entrepreneurial performance, and entrepreneurial competences and formulate a set of hypotheses. The methodology is presented in Section 3, and the results are presented in Section 4. Hypotheses testing is presented in Section 5. The paper closes with the discussion in Section 6, and conclusion Section 7.

\section{Theoretical framework}

This section explores the link between female entrepreneurship, entrepreneurial competences, and entrepreneurial performance. It starts with a discussion on female entrepreneurship and the various measurement indicators of what constitutes entrepreneurial performance as used in this paper. Then follows a review of entrepreneurial competences as a concept, their link to entrepreneurial performance, and, finally, the hypotheses associated with each identified entrepreneurial competency.

\subsection{Female entrepreneurship ${ }^{1}$}

The role and importance of female entrepreneurs and their contribution to a country's economies have been on the increase in last three decades (Brooks, Donovan, \& Johnson, 2018; Sarri \& Trihopoulou, 2005). Similarly, investigation of factors that impede the growth of female entrepreneurs has also grown, especially in the developing countries due to the existence of different factors that affect them (Jennings \& McDougald, 2007; St-Arnaud \& Giguère, 2018). Several studies, see Creighton et al., (2006); Maden, (2015); Sadler-Smith, Hampson, Chaston, \& Badger, (2003) have pointed to other challenges including financial capital, education, professional

\footnotetext{
${ }^{1}$ This paper has been prepared as part of a broader Ph.D. series of papers where the section on Female Entrepreneurship has been retained as the same across all the four papers.
} 
experience, family responsibilities and gender-related problems. Other challenges can also be classified as specific to different contexts and status such as cultural norms and beliefs (Jennings \& McDougald, 2007; Lock \& Lawton Smith, 2016; Naguib \& Jamali, 2015).

Female entrepreneurs participate not only in industries where they are traditionally active, but also are taking up active roles in less traditional sectors such as manufacturing, construction, and transportation, as well as in new growth areas such as financial services and communication (Bardasi, Sabarwal \& Terrell, 2009; Sarri \& Trihopoulou 2005). In Africa, they are more often likely to work in the service industry than male entrepreneurs do (Meyer \& Landsberg, 2015). These authors further argue that females are also more likely to work in government, health, education, and social services than their male counterparts as these sectors, mostly require a lower level of skills and show fewer barriers to entry, and they also have a relatively quick turnover and do not require long-term investments.

However, challenges abound that affect female entrepreneurs. These include limited access to start-up capital, government regulations, low levels of education, lack of business knowledge and lack of support during either decline or increase in business activity (Vuuren \& Groenewald, 2007). Other challenges are female specific such as lack of business management skills, inter-role conflict, lack of training and education, high-risk averseness, lack of female role models, inequality in access to credit and pressure of childcare responsibilities (Jamali, 2009b; Lebakeng, 2008).

Similarly, Isaga (2018) reinforced this point by suggesting that female entrepreneurs, just like male entrepreneurs in developing countries, are constrained by a lack of infrastructure; unstable business, economic and political environment and the general lack of entrepreneurship-related training. These business impediments is also attributed to the fact that many female entrepreneurs have low or lack access to formal education, access to real estate for use as collateral and social mobility (Creighton et al., 2006; Jamali, 2009b). Other factors that affect effective performance of female entrepreneurs include, negative perception that entrepreneurship is an appropriate career choice for males and not females; work-family conflict such as the combining of business with family responsibilities due to the pressure to conform to accepted gender roles (Jamali, 2009a; Jennings \& McDougald, 2007; St-Arnaud \& Giguère, 2018). Others like Dayhookoomsing (2003), in a study conducted in Mauritius, found out that, female entrepreneurs also face difficulties in getting permits as well as accessing markets.

Brixiová and Kangoye (2016) and Robb and Watson (2012) argued that there is not much difference in firm performance between female-owned and male-owned new ventures provided that this performance is measured appropriately. They further argue that risk aversion and firm size can be adjusted for gender differences. For instance, Justo, DeTienne, \& Sieger (2015), using a sample size of 219 former entrepreneurs in an attempt to determine why female entrepreneurs fail more than male entrepreneurs, found out that female entrepreneurs are more likely to exit voluntarily and for personal reasons.

Bardasi et al. (2009) demonstrated that female entrepreneurs owned small firms mostly because they are resource-constrained and industry-constrained. Vossenberg (2013) also noted that female entrepreneurs firms are concentrated in crowded areas and lowcost premises, and exhibit growth, employment, and profitability challenges (Kiggundu, 2002). 


\subsection{Entrepreneurial performance ${ }^{2}$}

In this paper, entrepreneurial performance is defined as firm performance, development of personal wealth and social performance, for reasons listed below. Firm performance is measured as firm growth in terms of growth in profits, growth in sales, growth in assets, and growth in the number of employed people/employment. Development of personal wealth involves the acquisition of wealth at the household level. Social performance involves the interaction of the entrepreneur with her community. We, therefore, can define entrepreneurial performance as the achievements delivered by people running their enterprises. So by its very definition measuring firm performance is logical. Also measuring the development of personal wealth by the entrepreneur is logical because the entrepreneur is the crucial person within the firm. And as the firm cannot be seen in isolation from its environment, it is also logical that we look at the impact a firm has on the society in which it operates in. See also, (Shane \& Venkataraman, 2000).

There are three critical points to consider while measuring the performance of small businesses, such include; the choice of performance indicator, the period under study, and the calculation to be undertaken (Delmar, 2006). For example, Delmar (2006), advises on the use of employment, sales or annual turnover data to measure performance, mainly because this data is readily available and is seen to be largely noncontroversial from a respondents view. Similarly, profits and assets can be used as a measure of growth where the respondent is asked to rate themselves against their closest competitor in the industry or their own performance goals.

Many indicators, both quantitative and qualitative, may be used to measure the growth of small business (Isaga, 2012; Koufteros, Verghese \& Lucianetti, 2014). When using quantitative measurements, firm growth has several indicators that can be measured; these include growth in profits, growth in assets, growth in sales and growth in the number of employed people or employment. Shepherd et al. (2009) argued that sales growth is the most popular indicator of firm growth followed by employment growth. Sales growth is the most popular indicator because entrepreneurs often use this indicator when making business decisions. The employment growth indicator is also deemed appropriate because entrepreneurs are willing to disclose this type of information and it is also easier to recall (Isaga, 2017; Krueger, Reilly, \& Carsrud, 2000). Other authors in their studies of emerging economies have identified growth in the number of employees as the main indicator that is usually provided by entrepreneurs (Pouw \& Elbers, 2012, Eijdenberg, Paas \& Masurel, 2015).

All the above-mentioned indicators can be measured in terms of objective and subjective ways. González-Benito \& González-Benito (2005) suggested the use of subjective measures because they facilitate the measurement of complex dimensions of performance. Delmar, Davidsson, and Gartner (2003) distinguished perceptual growth and objective growth measures. The main difference between the two is the change as perceived by the small enterprise owner which can be more personal/subjective and the objective side which is measured by actual small enterprise growth, in terms of figures and numbers (Eijdenberg et al., 2015).

In measuring the development of personal wealth, we have used consumer durables as indicators like buying or building a house, having children in high-cost private schools, acquisition of financial assets (such as stocks, treasury bills, checking accounts, savings bonds \& accounts, and trusts), increasing the number of assets (such as rental houses), contribution to employee pension plans, and general household prestige such as having a satellite television. Such measures as used in the development of personal wealth vary

\footnotetext{
2 This paper has been prepared as part of a broader Ph.D. series of papers where the section on Entrepreneurial Performance has been retained as the same across all the four papers.
} 
from one country to another and may be based on national surveys and primary data, see the example of Pouw and Elbers (2012). See also Carter (2011).

In summary, the development of personal wealth, as used in this paper relates to the acquisition of household wealth which depends upon the performance of firms run by the female entrepreneurs; these wealth acquisitions are based at a household level rather than at the firm level. However, as Eijdenberg et al. (2015) argued, households in most poverty research efforts in emerging economies have been found to be headed by breadwinners who are often the owners of micro and small enterprises.

In operationalizing the social performance of the female entrepreneurs, we measured their interaction with their communities and society. As Hanson (2009) argued, female entrepreneurs gauge the success of their businesses as a proportion of the welfare provided to the community through creating a hybrid system of a firm that acts both as a business and as a not-for-profit organization. Hanson (2009) identified such nature of female-led firms as one example of the difference between female entrepreneurs and male entrepreneurs. Hanson (2009)further argued that female entrepreneurs use their enterprises as a way of conducting voluntary activities in areas in which they operate. We looked at such issues as the welfare of employees, assistance to orphans and the poor, and participation in civic duties such as payment of taxes.

Entrepreneurial performance has been defined differently by different scholars to include the ability to recognize new market opportunities. Others include the realization of such capacities as critical thinking, creativity, reflection, optimism and imagination that supports self-efficacy and self-directed learning in the face of failure (Delmar et al., 2003; Markman, Baron, \& Balkin, 2005). The lack of definite description of what represents entrepreneurial performance was further confirmed by Littunen, (2000), who described the concept to include, among others, existence of innovative behavior, business growth and employee satisfaction. Others like Hvide and Møen, (2007) have established a link between founders personal wealth and start-up performance, others too, have established that, investing in social networks with people inside and outside the firm, achieves growth (Franco, Haase, \& Pereira, 2016). Further, Kusyk \& Lozano, (2007) in assessing the performance of SMEs established that it is also logical to focus on the use of non-financial measures in measuring entrepreneurial performance. In this paper, entrepreneurial performance is conceptualized to be determined by the degree of improvement on firm performance, the development of personal wealth and social performance.

\section{Entrepreneurial competences}

In our paper, the term "competency"' is defined as in the Oxford English Dictionary (OED) as 'being able to do "something".' Thus, entrepreneurial competences can, therefore, be seen as necessary personal attributes to perform well as an entrepreneur (Shane, Locke, \& Collins, 2003) and Man, Lau, \& Chan, (2002) describe entrepreneurial competences as entrepreneurial "motives" or "motivational concepts" and "motivations," which emphasize how an individual can be described as a successful entrepreneur. Other authors may use different terms to describe entrepreneurial competences.

The first seven entrepreneurial competences discussed below have been adopted from the work of Shane et al., (2003). These are needed for achievement, locus of control, tolerance of ambiguity, risk-taking propensity, self-efficacy, egoistic passion, and goal setting.

The additional five competences were added to our study after a pre-study with experts in Kenya. These competences include innovativeness, resilience, trustworthiness; emotional stability; and patience. The justification of each choice can be found from 
the scientific sources cited under each competence. We deliberately chose to mention also several old sources to show the origins of these competences.

The next subsections explore each specific entrepreneurial competency in turn and then hypothesize why it might have a positive influence on entrepreneurial performance in terms of firm performance, the development of personal wealth, and social performance. In each of the following 12 sections (2.2.1 to 2.2.12), the main hypothesis is presented, and in our analysis section, the testing of the hypotheses is split up into three: one regarding firm performance, one regarding the development of personal wealth, and one regarding social performance.

\subsection{Need for achievement}

El-Namaki, (1988) and Rauch \& Frese, (2000)posit that individuals who have a higher need for achievement want to offer solutions themselves, set objectives themselves, and strive to meet them through their efforts (Isaga, 2012). Ismail et al., (2015), agree that persons with a higher need for achievement habitually find their way to entrepreneurship and accomplish their goals better than those with a lower need for achievement. The foundation for this proposition is that people with a higher need for achievement devote a considerable amount of time on how to do a job better, or how to accomplish what they consider significant to them, (Antonio, Lanawati, Wiriana, \& Christina, 2014).

Several scholars have supported the idea that the need for achievement is an entrepreneurial characteristic that can be used to differentiate entrepreneurs from other people as well as prosperous from ineffective firms (Rauch \& Frese, 2000). This argument is further sustained by the two meta-analyses piloted by Collins, Hanges, \& Locke, (2004) and (Rauch \& Frese, 2007). They found that the need for achievement is significantly linked with both the choice of an entrepreneurial career and firm performance. Thus we derive the following hypothesis:

$H 1$ Need for achievement is positively related to entrepreneurial performance

\subsection{Locus of control}

Locus of control refers to an individual's seeming ability to affect events in his/her life (Isaga, 2018). "Internals" have faith in that they have power over outcomes through their talents, efforts, or abilities, while "externals" trust that forces outside their control determine outcomes (Rotter, 1966). In the entrepreneurship literature, the locus of control has remained of considerable importance and has been considered to be one of the most vital traits of entrepreneurs (Rauch \& Frese, 2007). The internal locus of control relates to entrepreneurship since entrepreneurs believe that their activities, determine the rewards they achieve (Rauch \& Frese, 2007).

Internal locus of control is likewise included among the aspects which differentiate successful entrepreneurs from failed ones (Poon, 2006; Rauch \& Frese, 2007). Entrepreneurs with high levels of internal locus of control believe that they can control outcomes, and therefore, put more effort into realizing the envisioned results, which in turn aids them in initiating an enterprise and run it successfully (Isaga, 2012).

Rotter, (1966) hypothesized that entrepreneurs with an inner locus of control were more likely to strive for accomplishment compared with those with an external locus of control. It is believed that locus of control could be used to differentiate between those who are successful and those who are unsuccessful. Therefore, we derive the following hypothesis:

H2 Locus of control is positively related to entrepreneurial performance 


\subsection{Tolerance of ambiguity}

Budner, (1962) in a seminal paper, defined tolerance of ambiguity as to the inclination to look at circumstances without precise results as being attractive rather than threatening. Thus, tolerance of ambiguity can be conceptualized as a person's attitude concerning taking risks in decision-making circumstances (Sexton \& Bowman, 1985). While there is a lack of adequate evidence to configure a situation, an ambiguous state of affairs is said to prevail (Koh, 1996). Consequently, it has been argued that only people with a higher tolerance for ambiguity are able to survive in unstable conditions (Chenhall \& Langfield-Smith, 2007). Some researchers have shown that entrepreneurs have a considerably higher capacity to tolerate ambiguity than conventional managers (Koh, 1996; Teoh \& Foo, 1997). The results are supported by the idea that entrepreneurs adapt to situations and innovation prospects that are less than uncertain, and take the decisive charge for the choices they make (Antonio et al., 2014; Kadir, Salim, \& Kamarudin, 2012).

Moreover, researchers have provided robust support for the inference that tolerance of ambiguity is a significant attribute for entrepreneurs (Koh, 1996; Teoh \& Foo, 1997).. The challenges and probabilities associated with business advancement are, by their exact nature, erratic. As a result of this, entrepreneurs are required to have a substantial tolerance of ambiguity and view ambiguity as an exciting incentive rather than an understandable risk (Frank, 2014). Koh, (1996) in his seminal paper, argues that, when there is inadequate evidence to structure a situation, an uncertain situation is said to exist. He further states that a person of high tolerance of ambiguity endeavours to overcome such a situation. (see also Norton \& Moore, 2002; and Rose, Kumar, \& Yen, 2006).

Businesspersons do not only operate in an uncertain setting, and they are willing to seek out and manage uncertainty. Thus we derive the following hypothesis:

$H 3$ Tolerance of ambiguity is positively related to entrepreneurial performance

\subsection{Risk-taking propensity}

Risk-taking is defined as the "exercise of doing things that comprise of risks to achieve something" (Antonites \& Wordsworth, 2009). In crafting upon this concept, there have been many delineations and conceptions regarding risk-taking (Isaga, 2012). From a considered point of view, risk can be termed as endeavouring into the unknown, requiring a relatively large portion of resources or borrowing profoundly (Brockhaus, 1980). Brockhaus, 1980; Leyden, Link, \& Siegel, (2014) and Morgan \& Sisak, (2016) propound the idea that the primary aspect that differentiates an entrepreneur from an appointed employee is the ambiguity and the risk associated with self-employment. Built on this argument; therefore, a risk-taker is an individual who seeks out a business idea when the likelihood of succeeding is rather low (Segal, Borgia, \& Schoenfeld, 2000).

Begley and Boyd, (1987), in a seminal paper, argued that there was often a need for entrepreneurs to assent to ambiguity concerning financial health, psychological wellbeing, livelihood security, and family relationships. Also, some concepts of entrepreneurship regard the entrepreneur as bearing enduring uncertainty. Cacciotti, Hayton, Mitchell, and Giazitzoglu, (2016) argue that, individuals who are driven by a higher motivation for achievement would participate in undertakings of intermediaterisk because they offer a challenge and give the impression of being attainable.

People who score, extraordinary on the motive to evade failure circumvents common risks (Shane et al., 2003). As an alternative, they desire easy and safe activities (because there is an excellent chance of accomplishment) or exceedingly challenging and uncertain ones (since it is stress-free to explain failure devoid of accepting individual blame). Accordingly, risk-taking propensity has been well-defined in the entrepreneurship literature as the "inclination to take reasonable risks" (Isaga, 2012; 
Shane et al., 2003). Brockhaus, (1980) and Watson and Robinson, (2003) propose that risk-taking, alongside with creativity and flexibility, is an enhanced pointer of the probability of starting a business than is attainment motivation as argued by Sexton and Bowman, (1985) and Stewart, Watson, Carland, and Carland, (1999). Therefore, we suggest the following hypothesis:

H4 Risk-taking propensity is positively related to entrepreneurial performance

\subsection{Self-efficacy}

Overall, the meaning of self-efficacy is comparatively constant across the available literature (Isaga, 2012, 2017). Bandura, (1977), in a seminal paper, identified selfefficacy as strong ability in one's capability towards performing a particular task. Considerable effort has been concentrated on this aspect since it is assumed that people who have a stronger self-belief have a higher chance of starting a business that succeeds than individuals who have inferior self-efficacy (Judge, Erez, Bono, \& Thoresen, 2003). Furthermore, it can be said that entrepreneurs with a higher level of self-efficacy tend to set challenging targets, keep persisting even in the manifestation of failure, and approach these problematic tasks as challenges to be overcome rather than matters to be avoided (Rauch \& Frese, 2007). Shane et al., (2003) argue that: self-efficacy for a precise task has been presented to be an essential predictor of one's performance and can help illuminate why people of equivalent ability perform differently.

These traits of self-efficacy may be critical to the entrepreneurial process since these situations are often uncertain ones in which work, tenacity, and preparation are essential ((Shane et al., 2003). Due to the dynamic role of self-efficacy, much experiential effort has been made to investigate the effect of this on firm performance (Isaga, 2012). Likewise, (Anna, Chandler, Jansen, \& Mero, (2000), Baum, Locke, and Smith, (2001) and Baum and Locke, (2004) identified a positive relationship between the self-efficacy of entrepreneurs and the development of firms. Thus we focus on the role of selfefficacy on entrepreneurial performance is appropriate. Baum and Locke, (2004) established a robust, active relationship between self-efficacy and work-related performance, demonstrating that self-efficacy is an entrepreneurial feature that might anticipate performance. Therefore we derive the following hypothesis:

$H 5$ Self-efficacy is positively related to entrepreneurial performance

\subsection{Egoistic passion}

Shane et al., (2003) describes egoistic passion as the fervent, self-centered love for work. They further argue that the ego is a vital motive. The real individualist passionately loves the work; they love the practice of building a business and making it profitable (Kamil, Oksoy, \& Ozsoy, 2011). One is inspired to do what is essential within their importance and to do all that is necessary to achieve this (Haber \& Reichel, 2007). When entrepreneurs chase an opportunity, they must also take action that is substantial to make it real and achievable (Baum et al., 2001).

Enthusiasm stimulates the degree to which entrepreneurs pursue to create something great, vital, and essential when they pursue prospects (Kamil et al., 2011). The nature of entrepreneurial enthusiasm includes generating money and the yearning to create something new, from start to finish (Haber \& Reichel, 2007). Motivation translates into setting high goals for oneself and others (Shane et al., 2003). Therefore we present the following hypothesis:

H6 Egoistic passion is positively related to entrepreneurial performance

\subsection{Goal setting}

Locke and Latham, (2006) argue that goal setting is applied effectively on any realm in which an individual or group has some control over some of the endings. They further 
posit that it can be applied not only to work based tasks, but also to domains such as sports and rehabilitation, and can be applied in many other settings. Thus, the goals that the entrepreneurs set for each outcome are considerably related to their comparable outcomes (Tumasjan \& Braun, 2012). Baum et al., (2001), in their study of architectural woodworking firms, established that development goals were significantly related to the subsequent growth. The quantitative measures of goal difficulty and performance are related to each other (Shane et al., 2003). Shane et al., (2003) argue that attaining high-set goals require enormous energy and stamina. It can also be said that higher goals can lead to better performance outcomes than modest or low set goals. Therefore, we posit the following hypothesis:

$H 7$ Goal setting is positively related to entrepreneurial performance

\subsection{Innovativeness}

Innovativeness is an element of human personality which helps entrepreneurs nurture innovations in their firms (Isaga, 2012, 2017). It emphasizes a dynamic approach to innovation, such as the entrepreneurs' day-to-day efforts to advance their work processes (Utsch \& Rauch, 2000). Due to its dynamic role, many studies have connected innovativeness to entrepreneurship and the development of businesses (Isaga, 2012). For instance, Koh, (1996) surveyed MBA students in Hong Kong and established that the students who showed higher innovative behavior were more probable to want to start their firm (Isaga, 2012, 2017). Experiential evidence for this connection has been found in many studies, including those from both Western countries and emerging countries, e.g. (Gürol \& Atsan, 2006; \& Ishfad et al., 2010).

From this definition, it is clear that innovativeness is a predictor of intent to start a business (Isaga, 2012). Subsequently, innovativeness has regularly been found to have a significant influence on the growth of SMEs. see Carland, Hoy, Boulton, Carland, \& Carland, (1984), which is further reinforced by two meta-analyses, by Hult, Hurley, and Knight, (2004); Utsch and Rauch, (2000), which specified that innovativeness is related to business performance. The results of the meta-analysis, as mentioned in the above studies showed that innovativeness is among the key aspects that describe an entrepreneur and can be used to differentiate between successful and unsuccessful firms (Hult et al., 2004; Tajeddini, Elg, \& Trueman, 2013). Carland et al., (1984) theorized that entrepreneurs have a disposition for innovative activities, which combine resources in ways that generate profit and growth. In doing so, an entrepreneur has a greater predilection for innovation than other individuals. Therefore, we suggest the following hypothesis:

H8 Innovativeness is positively related to entrepreneurial performance

\subsection{Resilience}

Studies have suggested that resilience might be a factor in the definition of entrepreneurial success (Ayala \& Manzano, 2014; G. D. Markman \& Baron, 2003). Connor and Davidson, (2003) define resilience as the human aptitude to adapt in the face of tragedy, strain, and other hardships. Resilience can be used to characterize persons who are capable and effortlessly overcome their setbacks quickly, whether related to their lives or career ambitions (Zautra, Hall, \& Murray, 2010).

Entrepreneurs employ resilience as a response mechanism when confronted with hostile situations, and can marshal resources that they often do not envisage that they possess. Thus, Ayala and Manzano, (2014) conclude that resilience embodies a real growth strategy for entrepreneurs. Entrepreneurs are not easily discouraged when faced with adversarial situations; their actions are bold, and they fight to attain their goals (Powell \& Baker, 2011).

Resilient entrepreneurs have better capacity and aptitude to renew themselves over time through innovation and the adjustment to varied and tempestuous changes in the 
environment (Sutcliffe \& Vogus, 2003). Connor and Davidson, (2003) argue that resilience foresees entrepreneurial success and contributes to the description of why an entrepreneurial action achieves or does not achieve entrepreneurial success. Thus we present the following hypothesis;

H9 Resilience is positively related to entrepreneurial performance

\subsection{Trustworthiness}

The cultivation and development of individual relationships lead to the establishment of a shared trust demeanour, promotion of understanding and involvement, and the development of networks between partners (Gulati \& Kellogg, 1998). Shenton, (2004) identifies an individual relationship as a bond of trust, responsibility, and customization, all of which can be engendered between formal and informal behaviors. According to Tu, Hwang, Chen, and Chang, (2012), dependent on the responsibility of individuals, personal relations may go beyond immediate economic benefits and instead become based on trust and mutual obligation. When individuals start a business, they may acquire encouragement, self-confidence, and mutual support from their families and friends (Tu et al., 2012)

Trust begins with choosing and assigning tasks to trustworthy people and demonstrates the readiness of the entrepreneur to trust (potential) business partners such as suppliers, investors, and customers (Caliendo, Fossen, \& Kritikos, 2012). Shared trust among trading customers permits for profitable transactions, explicitly when business activities cannot be formalized through contracts (Caliendo et al., 2012). The willingness to trust reduces or lowers the risks of entrepreneurial activities. For instance, Porta, Lopez-de-silanes, Shleifer, and Vishny, (1997), in a seminal paper, pointed out that entrepreneurs who trust others during business transactions have a better chance of growing their firms. Within the entrepreneurial setting, trustworthiness as a personality characteristic refers to the degree that entrepreneurs believe they can rely upon and trust others (Caliendo et al., 2012).

Being in a position to trust other individuals is a precondition for realizing interchange processes in business, mainly when the venture is in its start-up phase, and when, for example, the legal processes are in their formative stages, such as when contracts are yet to signed (Caliendo et al., 2012). The willingness to trust reduces or lowers the risks of entrepreneurial activities. The following hypothesis is suggested:

H10 Trustworthiness is positively related to entrepreneurial performance

\subsection{Emotional stability}

The ups and downs of entrepreneurship have its emotional side, so emotional stability is an essential quality for successful entrepreneurs. Entrepreneurship as an undertaking is a multifaceted and accumulative process, where psychosomatic and social forces are foremost and may lead to the success or failure of an enterprise (Markman, 2003). Markman, Baron, \& Balkin, (2005) explain how the failing business venture combined with the 'obscure-side' of entrepreneurship could reinforce the entrepreneur's resistance to a balanced solution, and make the consideration of substitutes painful and non-existent. The following hypothesis is suggested;

H11 Emotional stability is positively related to entrepreneurial performance

\subsection{Patience}

The evolution from a modest operation to a larger one is associated with growth (Shane et al. 2003). The question here was whether the entrepreneur could cope with the extra demands both in expertise and competence as well as being able to accomplish the process of development of each scale effectively, as well as maintaining motivation and focus (Aldrich \& Cliff, 2003; Carroll \& Mosakowski, 1987; Shane et al., 2003). 
Developing such a kind of expertise takes patience. For instance, the entrepreneur needs to recruit workers who are in a position to learn and willingly go through a process of understanding the firm's products, processes, and competitors (Markman \& Baron, 2003). We, therefore, suggest the following hypothesis:

H12 Entrepreneurial patience is positively related to entrepreneurial performance

\section{Methodology}

In this section, the setting of the study, the selection of the sample, and the development of the questionnaire are dealt with.

\subsection{Study setting ${ }^{3}$}

Kenya's population is estimated at around 46.9 million in the year 2016, with a projected increase of an estimated one million yearly from 2008 to 2018 (OECD, AFDB \& UNDP, 2017). Kenya's Gross Domestic Product (GDP) is estimated to have expanded by 5.8 per cent in 2016 compared with a growth of 5.7 percent in 2015 (OECD et al., 2017). The service industry recorded an improved growth of 13.3 percent in 2016 compared with a contraction of 1.3 percent in 2015. Other sectors with significantly enhanced performance were information and communication, real estate, and transport and storage (Kenya National Bureau of Statistics, 2017a).

In the year 2014 Kenya's economic status was revised to that of a lower middle-income country. The reclassification placed Kenya as an emerging economy following the change in the size of its economy which showed a growth of the gross national income (GNI) at about USD 1,160 which surpassed the minimum threshold of USD 1,036 set by the World Bank (The World Bank, 2016).

Kenya has an educated and skilled populace and abundant natural resources including hydro and geothermal power (Cravo, Hornsby, Nascimento \& Santos, 2014). The country's membership of the East African Community and the Common Market for Eastern and Southern Africa makes Kenya a leader in foreign direct investment both for the East African market and the Central African market due to increased competitiveness as an investment destination and a communications hub for regional business and commerce (Cravo et al., 2014).

Challenges encountered include the persistent drought in 2016 which impacted negatively on agriculture and the electricity supply (Kenya National Bureau of Statistics, 2017b). Annual average inflation reduced to 6.3 percent in 2016 compared with an average of 6.6 percent in 2015, driven by the decline in prices of transportation, housing and utilities, and communication (Kenya National Bureau of Statistics, 2017b). Domestic credit, defined as the total amount of bank loans and government borrowing, declined from 20.8 percent in 2015 to 6.4 percent in 2016, mainly on account of reduced credit to the private sector (Kenya National Bureau of Statistics, 2017b; OECD et al., 2017).

Uasin Gishu County, where the data collection for this paper took place, is located in the Great Rift Valley, Western Kenya, and covers an area of 3,345.2 $\mathrm{km}^{2}$. The county is on a highland plateau with altitudes gently falling from 2700 meters above sea level (Forest \& Kali, 2009). According to the population census of the year 2009, the population in this county was 894,179 and is expected to rise to $1,211,853$ in the year 2015 , with a projected growth rate of 3.8 per cent by the year 2019. Uasin Gishu County has relatively high poverty levels, standing at 51.3 percent in the year 2015; this level is comparable with the national rate of 47.2 percent (Kenya National Bureau of Statistics, 2017b).

\footnotetext{
${ }^{3}$ This paper has been prepared as part of a broader Ph.D. series of papers where the section on Study Setting has been retained as the same across all the four papers.
} 
The empirical study was carried out on a sample of registered female entrepreneurs operating in the retail trade sector of Uasin Gishu County. Experts also recommended the choice of the trade sector. This county is an appropriate place for study because female entrepreneurs are generally highly regarded here, and the county also forms the catchment site of the overall ASALI project (ASALI stands for A Sustainable Approach to Livelihoods Improvement) which is the primary sponsor of this research. Besides, female entrepreneurs comprise an interesting and appropriate study population because of their unique characteristics of high family support and social participation, especially in this part of Kenya (De Vita, Mari \& Poggesi, 2014).

\subsection{Questionnaire development}

The research framework was adapted from Koh, (1996), who proposes, amongst other things, that certain entrepreneurial traits incline entrepreneurs towards higher levels of performance that differentiate them from non-entrepreneurs. This argument was also supported by the works of Krueger et al., 2000; Stephan and Pathak, 2016). The variables selected for this investigation are reflected in the hypotheses outlined above. The survey instrument involved the use of a fixed-alternative questionnaire. Fixed-alternative inquiries facilitate the ease of scoring to ensure high response rates. (See Koh, 1996). Such a design facilitates the coding and analysis of data. The survey instrument consists of two parts. The first part measures selected demographic variables; this was meant to develop a profile of the female entrepreneurs (Ibid).

The second part required the female entrepreneurs to state to what extent each of the twelve entrepreneurial competences applied to them. We presented three propositions per entrepreneurial competency and requested the female entrepreneurs to indicate their level of agreement on all 36 propositions (for details see appendix 1 nos. 601a to 612c) presented with a 5-point Likert scale ranging as follows: strongly disagree, disagree, neither agree nor disagree, agree, strongly agree. We acknowledge that our approach was based on self-perception and self-reporting of the female entrepreneurs. Each set of three propositions contained one statement that was reverse-scored and placed in between the other two to reduce response bias and the halo effect. Preceding scholars have described high internal reliability for such measures (Koh, 1996; Rose et al., 2006; Teoh \& Foo, 1997).

On Emotional stability as a competence we used the Core Self-Evaluation Scale (CSES), as developed by Judge et al., (2003), with 3 out of 12 items placed on a 5-item Likert scale ranging from "strongly agree" to "strongly disagree." Trustworthiness was measured using the scale used by Evans \& Revelle, (2008), with 3 out of 21 items again placed on a 5-point Likert scale. These two measures were also confirmed to be valid by the experts during the pre-data collection exercise (see below).

We conducted a pre-study consisting of crucial in-depth informant interviews preceding the main study, which involved the collection of quantitative data. The prestudy reached 30 experts on female entrepreneurship ranging over financial institutions, development civil societies (non-governmental organizations, NGOs), national government officials, local government officials, chamber of commerce, female traders associations, and trade licensing officers. No significant changes were recommended for the final items in the questionnaire.

The other 30 propositions were adapted from the unpublished work of Masurel and Groesbeek, (2014) that was based on the master's thesis of the latter. The propositions were also recommended for adoption by the experts during the pre-study. 


\subsection{Sampling ${ }^{4}$}

We developed the sampling from the total number of registered businesses in Uasin Gishu County which stood at 38,245 in the retail trade sector at the time of data collection. To determine the target sample size, we adopted a proportionate percentage of $47.7 \%$ as developed and established by Cutura (2006) who argued that the proportion of female entrepreneurs in business in Kenya at any cohort of micro, small, medium and large average $48 \%$ by sample size estimation. Thus the number of female entrepreneurs conducting business was 18,242 in Uasin Gishu County.

We conducted interviews in peri-urban centers, rural townships and within Eldoret town center. This meant that for every given population of the female entrepreneurs' everyone had a chance of being interviewed. For example, in urban settings, we interviewed every fourth female entrepreneur, and for the sparsely populated rural areas, we interviewed every second female entrepreneur. Eldoret town is the fifth largest town in Kenya. It was set up during the colonial government. It is known as a center for agriculture and trade in the Western Kenya region. It has an urban population of 289,380 as per the 2009 population census. Eldoret town forms the main economic hub in Western Kenya and is the capital of Uasin Gishu County government.

We, therefore, applied simple random technique, which is a sampling technique where there is a known non-zero chance of including the entire unit within the sample and where every respondent within the population has an equal chance of being selected and at the same time allowing for a statistical inference to be made. Further, the firms of the respondents from this sample met the following criteria, (1) firms that were formal and registered businesses, (2) firms that were owned and controlled by female entrepreneurs, (3) firms that were more than 3 years old and we also ensured that the firms had complete contact information on the female entrepreneur. However, as time was a major constraining factor, out of the 316 who agreed to participate in the study, 301 were accepted with 15 questionnaires being rejected for incompleteness.

\section{Results 5}

The fieldwork took place in April and May 2015. The capital of the Uasin Gishu County is Eldoret, which is a cosmopolitan city and serves as the foremost economic and political capital of North-Western Kenya. The field-work was divided into two phases. The first phase involved carrying out key informant interviews with various experts in the field of entrepreneurship. The second phase involved data collection, where we divided the county into four areas: the town centers, the outskirts, the peri-urban areas, and the rural townships.

In total, we collected data from 301 female entrepreneurs, From Table 1 it becomes clear that Less than 20 percent of the respondents had Basic Education (Classes 1-8) as their highest form of completed level of education, almost half of the respondents had Secondary Education (Forms 1-4) which was the highest level of education that they had completed. Almost one-quarter of the respondents had successfully acquired a College Diploma as their uppermost level of education. The other forms of education hardly occurred among our group of respondents. Close to a third, 33.2 percent of the respondents reported having had both prior business and management experience, correspondingly. It is important to note that the scores for both experiences are the same. The respondents may not have distinguished between the two.

\footnotetext{
${ }^{4}$ This paper has been prepared as part of a broader Ph.D. series of papers where the section on Sampling has been retained as the same across all the four papers.

${ }^{5}$ This paper has been prepared as part of a broader Ph.D. series of papers where the 1 st section on results for tables $1 \& 2$ has been retained as the same across all the three papers.
} 
From Table 1, it also becomes clear that almost half of the respondents were 30 years of age or younger. About one-third of the respondents ranged between 30 and 40 years of age. Slightly more than 20 percent were older than 40 years.

Table 1 Entrepreneur profile

\begin{tabular}{|c|c|c|}
\hline & Frequency & Percent \\
\hline \multicolumn{3}{|l|}{ Highest level of education } \\
\hline No education & 4 & 1.3 \\
\hline Basic Education (Class 1-8) & 48 & 15.9 \\
\hline Secondary Education (Form 1-4) & 149 & 49.5 \\
\hline Trade School (Certificate Holder) & 21 & 7 \\
\hline College Diploma & 66 & 21.9 \\
\hline University Degree & 10 & 3.3 \\
\hline Professional Qualification & 2 & 0.7 \\
\hline Other & 1 & 0.3 \\
\hline Total & 301 & 100 \\
\hline \multicolumn{3}{|l|}{ Prior Business Experience } \\
\hline With & 100 & 33.2 \\
\hline Without & 201 & 66.8 \\
\hline Total & 301 & 100 \\
\hline \multicolumn{3}{|l|}{ Prior Management Experience } \\
\hline With & 100 & 33.2 \\
\hline Without & 201 & 66.8 \\
\hline Total & 301 & 100 \\
\hline \multicolumn{3}{|l|}{ Age } \\
\hline Under 20 years & 14 & 4.7 \\
\hline 20 to 30 years & 126 & 41.9 \\
\hline 31 to 40 years & 99 & 32.9 \\
\hline 41 to 50 years & 40 & 13.3 \\
\hline 51 to 60 years & 21 & 7.0 \\
\hline Over 60 years & 1.0 & 0.3 \\
\hline Total & 301 & 100 \\
\hline
\end{tabular}

Table 2 presents the profile of the firms. The table illustrates that more than half of the firms have only been in business since 2010 . More than 40 percent was already in the business between 2000 and 2010. Only a small minority of 1 percent of the firms had already been in business on the old millennium. Further, almost half of the firms were located in the town center, whereas more than one-quarter of the firms were located in one of the rural townships. More than 10 percent of the firms were located in the outskirts of peri-urban areas. 
Additionally, more than half of the firms had employed three employees. More than 35 percent of the firms had employed one or two employees. Only a small minority employed four to five employees.

Table 2 Firm profile

\begin{tabular}{lll}
\hline Years of founding the Business & Frequency & Percent \\
1970 to 1980 & 3 & 1 \\
1990 to 2000 & 22 & 7.3 \\
2000 to 2010 & 123 & 40.9 \\
2010 to 2015 & 153 & 50.8 \\
Total & $\mathbf{3 0 1}$ & $\mathbf{1 0 0}$ \\
& & \\
Location & & \\
Town Centre & & 46.5 \\
Outskirts & 140 & 14 \\
Peri-Urban areas & 42 & 13 \\
Rural Townships & 39 & 26.2 \\
Other & 79 & 0.3 \\
Total & 1 & $\mathbf{1 0 0}$ \\
& $\mathbf{3 0 1}$ & \\
Number of people working for the firm & & 27.5 \\
1.0 & & 7.6 \\
2.0 & 83 & 51.7 \\
3.0 & 23 & 11.3 \\
4.0 & 155 & 1.9 \\
5.0 & 34 & $\mathbf{1 0 0}$ \\
Total & 6 & \\
\hline
\end{tabular}

In Table 3, all 12 entrepreneurial competences were subjected to exploratory factor analysis. Nine out of 36 propositions had factor scores of below .7 and were dropped during the factor analysis. Eventually, all scale items loaded between .706 and .846 . The explained variance ranged from 52.29 percent to 76.91 percent.

These measures of explained variance provide additional information beyond that provided by the mean scores and therefore indicate that our instrument was sufficiently reliable to measure entrepreneurial competences, and therefore, we could proceed with further analysis of our data (Podsakoff \& Organ, 1986). See also, Gelman \& Pardoe, (2006) and O’Grady, (1982). 
Table 3 Entrepreneurial competences: factor loadings and explained variance values

\begin{tabular}{|c|c|c|c|}
\hline Competence & Proposition & $\begin{array}{l}\text { Factor } \\
\text { loading }\end{array}$ & $\begin{array}{l}\text { Explained } \\
\text { Variance } \\
\end{array}$ \\
\hline Need for Achievement & $\begin{array}{l}\text { I never put off important matters } \\
\text { until at a convenient time } \\
\text { No matter how difficult a task is, I } \\
\text { try to do as best as I can }\end{array}$ & $\begin{array}{l}.818 \\
.818\end{array}$ & 66.96 \\
\hline Locus of Control & $\begin{array}{l}\text { I believe the outcome of many tasks } \\
\text { is determined by good or bad fortune } \\
\text { I believe when I get what I want it is } \\
\text { because I was determined to work } \\
\text { hard for it }\end{array}$ & $\begin{array}{l}.822 \\
.822\end{array}$ & 67.58 \\
\hline Tolerance of Ambiguity & $\begin{array}{l}\text { When I am in a situation where I } \\
\text { have no control, I feel very anxious } \\
\text { I always see the bigger picture }\end{array}$ & $\begin{array}{l}.772 \\
.772\end{array}$ & 59.56 \\
\hline Risk-taking Propensity & $\begin{array}{l}\text { People in our firm are encouraged to } \\
\text { take calculated risks with new ideas } \\
\text { Our firm emphasizes both } \\
\text { exploration and experimentation for } \\
\text { opportunities }\end{array}$ & $\begin{array}{l}.846 \\
.846\end{array}$ & 71.65 \\
\hline Self-efficacy & $\begin{array}{l}\text { When I get what I want its mainly } \\
\text { because I worked for it } \\
\text { When I set important goals for } \\
\text { myself, I do not always achieve } \\
\text { them }\end{array}$ & $\begin{array}{l}.793 \\
.793\end{array}$ & 62.95 \\
\hline Egoistic Passion & $\begin{array}{l}\text { I love my work } \\
\text { I accomplish a lot at work because I } \\
\text { love my work }\end{array}$ & $\begin{array}{l}.823 \\
.823\end{array}$ & 67.81 \\
\hline Goal Setting & $\begin{array}{l}\text { I like to commit myself to reach } \\
\text { particular results } \\
\text { I think it is important to set new } \\
\text { business targets regularly }\end{array}$ & $\begin{array}{l}.803 \\
.803\end{array}$ & 64.42 \\
\hline Innovativeness & $\begin{array}{l}\text { My firm actively introduces } \\
\text { improvements and innovations in } \\
\text { our business } \\
\text { My firm seeks out new ways of } \\
\text { doing things } \\
\text { My firm is creative in its methods of } \\
\text { operation }\end{array}$ & $\begin{array}{l}.804 \\
.797\end{array}$ & 76.91 \\
\hline Resilience & $\begin{array}{l}\text { I work harder than most people I } \\
\text { know }\end{array}$ & .840 & \\
\hline
\end{tabular}


I have never considered quitting my

firm, regardless of the problems I encounter

Trustworthiness

I anticipate the needs for others

I believe that laws should be strictly .815

enforced

I believe that laws should be strictly $\quad .795$

followed

Emotional Stability

I am confident I get the success I

.839

deserve in life

I am able to cope with most of my

problems

Patience

Finding an office job does not take .723

long

I expect a quick return on my .723 investment

Table 4 presents the findings of the Exploratory Factor Analysis, which was run on the constructs that define entrepreneurial performance. Firm Performance had one item out of four dropped due to low factor loading (increase in the number of employed people, with a factor loading of .277), three items were retained. Development of Personal Wealth had four items dropped for having factor loadings below 0.7 (I have been able to build/buy or start building a house, I have increased my assets (such as rental houses); I have contributed to my employees' pension plan (such as NSSF and NHIF), I have acquired Household Prestige - items (such as Satellite Television), with only two items being retained. The same process was repeated on Social Performance, where seven items were dropped (My firm offers industrial attachments, internships to students; My firm uses a formal customers' complaints register for clients; My firm improves the quality of life in communities where we operate; My firm donates money to charities in the communities where we operate; My firm makes timely payment of taxes; My firm is active within an organization with a social purpose; and My firm offers time and skills in voluntary activities), with only three items being retained. Although the majority of items were dropped, the three dimensions of entrepreneurial performance represent distinct constructs, and therefore, we could proceed to conduct a regression analysis (Hurley et al., 1997).

Table 4 Entrepreneurial Performance: Factor Loadings and Explained Variance Values

\begin{tabular}{lll}
\hline Firm Performance & $\begin{array}{l}\text { Factor } \\
\text { Loading }\end{array}$ & $\begin{array}{l}\text { Explained } \\
\text { Variance }\end{array}$ \\
\hline Development of my firm's profit & .815 & \\
Development of my firm's sales & .818 & 67.56 \\
Development of my firm's assets & .833 &
\end{tabular}

Development of Personal Wealth

I have managed to take my children to study in a high cost private school

I have managed to acquire financial assets (such as stocks, treasury bills, checking accounts, savings bonds and accounts, trusts) 


\section{Social Performance}

My firm supports orphans and the underprivileged in society directly or indirectly through existing institutions My firm sponsors community activities such as sports, church buildings, culture, and traditional ceremonies.

Table 5 shows the descriptive statistics, mean, standard deviation, and correlation coefficients of all the variables we used in the analysis. An interesting observation was that all the 12 competences had rather high mean scores ranging from 2.93 for "Patience" to 4.62 for "Trustworthiness." These high aggregate mean scores may be an indication that the entrepreneurial competences do exist among female entrepreneurs in Kenya. There were mixed outcomes on the levels of significance of the correlations. Additionally, there were no strong signs of multicollinearity problems in our data. The lack of extraordinary high coefficients $(r>0.70)$ was an indication of the presence of a measure of different concepts, and therefore the regression results presented in Table 6 may not be affected by collinearity (Pallant, 2010). Furthermore, the variance inflation factor coefficients scores were below 10 (for example, 2.292 for Patience and 1.274 for Innovativeness). Tolerance values were higher than .10 (for example, .436 Innovativeness and .785 Patience) among the independent variables.

On the other hand, there was a high degree of correlation among the dependent variables, suggesting that there could be a measurement of the same concept, viz., entrepreneurial performance. However, this high degree of correlations among these variables may not be problematic mainly because they were used to measure entrepreneurial performance independent of each other in the regression models presented in Table 6 . In carrying out the hypothesis testing, multivariate regression analysis was carried out to assess the contribution of each independent variable in explaining the variance of each entrepreneurial performance, as presented earlier in section 2.

\section{Hypotheses Testing}

In Table 6, as far as the entrepreneurial competence "Need for achievement" is concerned, Hypothesis 1 is rejected, as we do not see any significance, neither with firm performance, nor with development of personal wealth, nor with social performance. Hypothesis 2, on the entrepreneurial competence "Locus of control," is only significant with the aspect of social performance, whereas the other aspects of entrepreneurial performance (firm performance and development of personal wealth) are not significant. Therefore, Hypothesis 2 is partly accepted. For Hypothesis 3, on the entrepreneurial competence "Tolerance for ambiguity," there is no significant relationship with any of the performance indicators. This means that Hypothesis 3 is rejected. Hypothesis 4 on "Risk-taking propensity" as an entrepreneurial competence was found not to be significant with any aspect of performance. This means that Hypothesis 4 is rejected. Hypothesis 5 on "Self-efficacy" as an entrepreneurial competence was significant with only one aspect, namely the development of personal wealth: this means that Hypothesis 5 is partly accepted. Hypothesis 6 on "Egoistic passion" as an entrepreneurial competence has no significant relationship with any performance indicator. 
Table 5 Descriptive statistics, mean, standard deviation and correlation coefficients

\begin{tabular}{|c|c|c|c|c|c|c|c|c|c|c|c|c|c|c|c|c|c|c|c|c|c|c|}
\hline & & Mean & \begin{tabular}{|l} 
Std. \\
Deviation \\
\end{tabular} & 1 & 2 & 3 & 4 & 5 & 6 & 7 & 8 & 9 & 10 & 11 & 12 & 13 & 14 & 15 & 16 & 17 & 18 & 19 \\
\hline 1 & Age & 2.77 & 1.00 & 1 & & & & & & & & & & & & & & & & & & \\
\hline 2 & Education & 3.47 & 1.20 & $.195^{*}$ & 1 & & & & & & & & & & & & & & & & & \\
\hline 3 & Business Experience & 1.67 & 0.47 & $.198^{*}$ & $.168^{*}$ & 1 & & & & & & & & & & & & & & & & \\
\hline 4 & Employment Experience & 1.67 & 0.47 & $.247^{*}$ & .021 & $.611^{*}$ & 1 & & & & & & & & & & & & & & & \\
\hline 5 & Need for Achievement & 4.41 & 0.66 & $.122^{\circ}$ & .051 &. $.159^{* *}$ & -.089 & 1 & & & & & & & & & & & & & & \\
\hline 6 & Locus of Control & 4.54 & 0.52 & .109 & .012 & -.101 & $-.135^{*}$ & $.353^{\prime \prime}$ & 1 & & & & & & & & & & & & & \\
\hline 7 & Tolerance of ambiguity & 4.51 & 0.51 & .109 & $.140^{\circ}$ & -.074 & -.087 & $.339{ }^{\circ}$ & $.303^{*}$ & 1 & & & & & & & & & & & & \\
\hline 8 & Risk-taking & 4.18 & 0.64 & .093 & .069 & $-.156^{\circ}$ & $-.161^{*}$ & $.121^{\circ}$ & $.328^{*}$ & $.246^{\circ}$ & 1 & & & & & & & & & & & \\
\hline 9 & Self-efficacy & 4.33 & 0.54 & $.131^{\circ}$ & $.169^{*}$ & -.023 & -.095 & $.436^{*}$ & $.349^{*}$ & $.330^{*}$ & $.310^{*}$ & 1 & & & & & & & & & & \\
\hline 10 & Egoistic Passion & 4.66 & 0.54 & .016 & .026 & $-.196^{*}$ & $-.124^{\circ}$ & $.328^{*}$ & $.256^{\circ}$ & $.269^{*}$ & $.297^{*}$ & $.213^{*}$ & 1 & & & & & & & & & \\
\hline 11 & Goal Setting & 4.36 & 0.61 & .068 & .090 & -.040 & -.104 & $.291^{*}$ & $.327^{*}$ & $.311^{*}$ & $.412^{* *}$ & $.419^{*}$ & $.197^{*}$ & 1 & & & & & & & & \\
\hline 12 & Innovativeness & 4.28 & 0.67 & .058 & $.134^{\circ}$ & $-.150^{* *}$ & $-.164^{*}$ & $.371^{*}$ & $.517^{*}$ & $.295^{\prime \prime}$ & $.559^{* *}$ & $.521^{*}$ & $.274^{*}$ & $.448^{*}$ & 1 & & & & & & & \\
\hline 13 & Resilience & 4.47 & 0.70 & .113 & $.177^{*}$ & $-.215^{*}$ & $-.139^{\circ}$ & $.344^{*}$ & $.434^{*}$ & $.284^{*}$ & $.377^{*}$ & $.421^{*}$ & $.254^{*}$ & $.346^{*}$ & $: 484^{\circ}$ & 1 & & & & & & \\
\hline 14 & Trustworthiness & 4.62 & 0.46 & $.125^{\circ}$ & .116 & $-.172^{* *}$ & -.100 & $.293^{*}$ & $.362^{*}$ & $.325^{\prime \prime}$ & $.404^{*}$ & $390^{\circ}$ & $.254^{*}$ & $.401^{*}$ & $.433^{\circ}$ & $.518^{*}$ & 1 & & & & & \\
\hline 15 & Emotional Stability & 4.45 & 0.62 & .110 & .126 & $-.161^{*}$ & -.081 & $.437^{*}$ & $.415^{*}$ & $290^{\circ}$ & $.453^{* \prime}$ & $.382^{*}$ & $.400^{\circ}$ & $.344^{*}$ & $: 449^{*}$ & $.546^{\circ}$ & $.599^{*}$ & 1 & & & & \\
\hline 16 & Patience & 2.93 & 1.11 & -0.033 & .107 & .034 & -010 & $.203^{\prime \prime}$ & $.221^{*}$ & $.128^{\circ}$ & $.257^{*}$ & $.309^{*}$ & .098 & $.193^{*}$ & $: 401^{\circ}$ & $.265^{*}$ & .085 & $.123^{\circ}$ & 1 & & & \\
\hline 17 & Firm Performance & 3.63 & 0.70 & .004 & -.029 & .049 & $.130^{\circ}$ & $.115^{\circ}$ & $.129^{\circ}$ & .057 & .045 & $.154^{*}$ & .025 & $.153^{*}$ & $: 172^{\circ}$ & .032 & .041 & .023 & $.188^{*}$ & 1 & & \\
\hline 18 & Personal Wealth & 4.12 & 0.70 & .028 & .056 & $.142^{\circ}$ & .097 & .000 & .037 & .012 & .018 & .058 & .014 & $.117^{\circ}$ & .019 & .068 & .052 & .004 & $.159^{*}$ & .061 & 1 & \\
\hline 19 & Social Performance & 2.88 & 1.30 & .012 & .055 & $-.123^{*}$ & $-.140^{\circ}$ & $.300^{*}$ & $.496^{\circ}$ & $.205^{*}$ & $.387^{*}$ & $.431^{*}$ & $.188^{*}$ & $.445^{*}$ & $.616^{\circ}$ & $.517^{*}$ & $.385^{\prime \prime}$ & $.336^{\circ}$ & $.487^{*}$ & $.272^{*}$ & .107 & 1 \\
\hline
\end{tabular}


This means that Hypothesis 6 is rejected. Similarly, Hypothesis 7 on "Goal setting" as an entrepreneurial competence has no significant relationship with any of the entrepreneurial performance indicators, and thus Hypothesis 7 is rejected. Hypothesis 8 on "Innovativeness" is only significant with social performance. Firm performance and the development of personal wealth were not significant. The effect of this means that Hypothesis 8 is partly accepted. Hypothesis 9 on "Resilience" as an entrepreneurial competence had a significant positive relationship with only one aspect of the performance indicators (social performance) and one significant negative relationship with the development of personal wealth. The implication of this is that Hypothesis 9 is partly accepted. Hypothesis 10 on the entrepreneurial competence "Trustworthiness" was partly accepted because only the relationship with social performance appeared to be significant. Hypothesis 11 on "Emotional stability" as an entrepreneurial competence was rejected because no significant relationship occurred. Finally, Hypothesis 12 on the entrepreneurial competence "Patience" was accepted, as there was a significant relationship with all three indicator's firm performance, development of personal wealth, and social performance.

Table 6 Regression Model Results

\begin{tabular}{|c|c|c|c|}
\hline $\begin{array}{ll}\text { Independent } & \backslash \text { Dependent } \\
\text { Variable } & \backslash \text { Variable }\end{array}$ & $\begin{array}{l}\text { Firm } \\
\text { Performance }\end{array}$ & $\begin{array}{l}\text { Development of } \\
\text { Personal Wealth }\end{array}$ & $\begin{array}{l}\text { Social } \\
\text { Performance }\end{array}$ \\
\hline Age & .018 & .013 & -.067 \\
\hline Education & -.023 & .019 & -.080 \\
\hline Business Experience & -.111 & .137 & .110 \\
\hline Employment Experience & $.306^{* *}$ & .050 & -.177 \\
\hline Need for Achievement & .033 & -.025 & .112 \\
\hline Locus of Control & .101 & -.082 & $.426^{* * *}$ \\
\hline Tolerance of Ambiguity & -.013 & -.024 & -.141 \\
\hline Risk-taking Propensity & -.068 & -.034 & -.051 \\
\hline Self-efficacy & .094 & $.019 *$ & .167 \\
\hline Egoistic Passion & -.007 & .053 & .117 \\
\hline Goal Setting & .134 & .157 & .300 \\
\hline Innovativeness & .126 & -.042 & $.408 * * *$ \\
\hline Resilience & -.091 & $-.167 *$ & $.385 * * *$ \\
\hline Trustworthiness & -.015 & .183 & $.328 *$ \\
\hline Emotional Stability & -.073 & .017 & -.137 \\
\hline Patience & $.083 * *$ & $.124 * *$ & $.267 * * *$ \\
\hline $\mathrm{R}^{2}$ & .104 & .084 & .629 \\
\hline Adjusted $\mathrm{R}^{2}$ & .053 & .033 & .609 \\
\hline
\end{tabular}

Significant coefficients reported $\mathrm{p}<.05^{*}, \mathrm{p}<.01^{* *}, \mathrm{p}<.001^{* * *}$

Table 7 presents an overview of the results of testing the 12 hypotheses. It appears that six hypotheses were rejected; five hypotheses were partly accepted, and only one hypothesis was accepted. 
Table 7 Summary

H1 Need for achievement is positively related to entrepreneurial performance

H2 Locus of control is positively related to entrepreneurial performance

H3 Tolerance of ambiguity is positively related to entrepreneurial performance

H4 Risk-taking Propensity is positively related to entrepreneurial performance

H5 Self-efficacy is positively related to entrepreneurial performance

H6 Egoistic passion is positively related to entrepreneurial performance

$H 7$ Goal setting is positively related to entrepreneurial performance

H8 Innovativeness is positively related to entrepreneurial performance

H9 Resilience is positively related to entrepreneurial performance

H10 Trustworthiness is positively related to entrepreneurial performance

H11 Emotional stability is positively related to entrepreneurial performance
Rejected

Partly accepted

Rejected

Rejected

Partly accepted

Rejected

Rejected

Partly accepted

Partly accepted

Partly accepted

Rejected

Accepted

\section{Discussion}

We observe that there was sufficient evidence to conclude that the entrepreneurial competences of female entrepreneurs, as studied in the Western context, are hardly related to the entrepreneurial performance of the trade firms in our sample. Another observation is that the factor analysis resulted in the dropping of a relatively large number of items.

First, it is essential to note that during the factor analysis of firm performance, the scale item on the increase in the number of employees was dropped. This may be because hiring more employees brings with it extra costs to the firm. In that sense, this item of firm growth is different from the growth of profit, sales, and assets that have more to do with the output of the firm, whereas the growth of the number of employees has more to do with the input of the firm.

Concerning the construct "development of personal wealth,": four out of six items had to be dropped, and the remaining two items had an adequate explained variance. The four items that were dropped have more to do with the immediate satisfaction of the entrepreneurs, whereas the two remaining items have more to do with the future satisfaction of the entrepreneurs. Nevertheless, the two remaining items that have to do with the satisfaction of the entrepreneurs in the future are still very diverse.

As far as "social performance" was concerned, seven out of ten scale items were dropped due to low factor loadings. A closer look at the retained scale items leads to the picture, where we suggest that these factors deal with direct-giving to the community by the female entrepreneurs. The group of dropped items could be said to involve a form of indirect giving to the community. 
"Social performance" had a partial relationship with the entrepreneurial competences with (5 out of 12 entrepreneurial competences), whereas "firm performance" had virtually no relationship with entrepreneurial competences (1 out of 12 competences), and "development of personal wealth" too had virtually no relationship to entrepreneurial competences ( 2 positives out of 12 competences). The latter may have to do with the regional economic context in which the entrepreneurs operate. We can posit that this phenomenon may be influenced by the nature of the female entrepreneurs, which is expected to combine commercial goals while simultaneously serving the needs of the communities that they belong to.

"Patience" is the only entrepreneurial competence that yields an accepted hypothesis. A possible explanation for this can be drawn from the nature of female entrepreneurs in emerging economies who work in very uncertain situations to develop a market presence with low economic power coupled with the predatory activities of more resourceful rivals; to overcome such challenges, it is necessary to have entrepreneurial patience. Female entrepreneurs may also endure harsh private difficulties, such as personal and financial liabilities, and long periods of isolation while developing their businesses. The ability to withstand and even overcome such adversity gives entrepreneurial "patience" an essential advantage over other entrepreneurial competences.

\section{Conclusion}

In this paper, we have attempted to answer the study question: To what extent do entrepreneurial competences contribute to the entrepreneurial performance of female entrepreneurs in Kenya. The answer to this question is predominantly "not": there is hardly any contribution of the entrepreneurial competences to the entrepreneurial performance. We can state that there is virtually no contribution of the entrepreneurial competences to firm performance and the development of personal wealth. We can also state that there is some contribution of the entrepreneurial competences to the social performance of the entrepreneurs involved.

It is critical to note that both the entrepreneurial competences constructs and the entrepreneurial performance constructs are present among the studied trade firms in Kenya. The finding that these entrepreneurial competences lack a positive correlation with entrepreneurial performance is not because these constructs cannot be identified, but rather because the entrepreneurial competences have hardly any effect on the entrepreneurial performance.

There were two significant limitations to this study. The first major limitation is that we studied only one sector in one region. The second major limitation is that the data collected was based on self-perception and self-reporting of the female entrepreneurs, which could have led to biased outcomes.

Having studied only one sector, viz. Trade, in one region, specifically Western Kenya, we first recommend that multi-sectoral and inter-regional studies should be conducted to confirm that there is hardly any relationship between entrepreneurial competences and entrepreneurial performance. Our second recommendation is that alternative research methods should be used as well, for instance, observation and peer reports.

\section{Acknowledgements}

This research was supported by the Ms Grietje Wille Legacy under the ASALI project (A Sustainable Approach to Livelihood Improvements), a joint cooperation between VU University, the Netherlands and Moi University, Kenya. We thank the two anonymous reviewers whose comments greatly improved this manuscript. The authors declare no conflict of interest. 


\section{References}

Aldrich, H. E., \& Cliff, J. E. (2003), The pervasive effects of family on entrepreneurship: toward a family embeddedness perspective. Journal of Business Venturing, 18(5), 573-596.

Almeida Cravo, T., J Hornsby, D., Nascimento, D., \& José Santos, S. (2014), African emerging powers. Norwegian Peacebuilding Resource Centre.

Anna, A. L., Chandler, G. N., Jansen, E., \& Mero, N. P. (2000), Women business owners in traditional and non-traditional industries. Journal of Business Venturing, 15(3), 279-303.

Antonio, T., Lanawati, S., Wiriana, T. A., \& Christina, L. (2014), Correlations Creativity, Intelligence, Personality, and Entrepreneurship Achievement. Procedia - Social and Behavioral Sciences, 115(2014), 251-257.

Antonites, A. J., \& Wordsworth, R. (2009), Risk tolerance: A perspective on entrepreneurship education. Southern African Business Review, 13(3), 69-85.

Ayala, J. C., \& Manzano, G. (2014), The resilience of the entrepreneur. Influence on the success of the business. A longitudinal analysis. Journal of Economic Psychology, 42, 126-135.

Bandura, A. (1977), Toward a unifying theory of behavioral change. Psychological Review, 84(2), 191-215.

Bardasi, E., Sabarwal, S., \& Terrell, K. (2009), How do Female Entrepreneurs Perform? Evidence from Three Developing Regions. Small Business Economics, 37(4), 417-441.

Bardasi, E., Sabarwal, S., \& Terrell, K. (2011), How do female entrepreneurs perform? Evidence from three developing regions. Small Business Economics, 37(4), 417-441.

Baum, J. R., \& Locke, E. A. (2004), The relationship of entrepreneurial traits, skill, and motivation to subsequent venture growth. The Journal of Applied Psychology, 89(4), 587-598.

Baum, J. R., Locke, E. A., \& Smith, K. G. (2001), A multidimensional model of venture growth. Academy of Management Journal, 44(2), 292-303.

Begley, T. M., \& Boyd, D. P. (1987), Psychological characteristics associated with performence in entrepreneurial firms and smaller businesses. Journal of Business Venturing, 2(1), 79-93.

Brixiová, Z., \& Kangoye, T. (2016), Gender and constraints to entrepreneurship in Africa: New evidence from Swaziland. Journal of Business Venturing Insights, $5,1-8$.

Brockhaus, R. H. (1980), Risk Taking Propensity of Entrepreneurs. Source: The Academy of Management Journal, 23(3), 509-520.

Brooks, W., Donovan, K., \& Johnson, T. R. (2018), Mentors or teachers? Microenterprise training in Kenya. American Economic Journal: Applied Economics, 10(4), 196-221.

Budner, S. (1962), Intolerance of ambiguity as a personality variable. Journal of Personality, 30, 29-50.

Cacciotti, G., Hayton, J. C., Mitchell, J. R., \& Giazitzoglu, A. (2016), A reconceptualization of fear of failure in entrepreneurship. Journal of Business Venturing, 31(3), 302-325.

Caliendo, M., Fossen, F., \& Kritikos, A. (2012), Trust, positive reciprocity, and negative reciprocity: Do these traits impact entrepreneurial dynamics? Journal of Economic Psychology, 33, 394-409.

Carland, J. W., Hoy, F., Boulton, W. R., Carland, J. A. C., \& Carland, J. O. a N. N. C. (1984), Differentiating Entrepreneurs from Small Business Owners. The Academy of Management Review, 9(2), 354-359.

Carroll, G. R., \& Mosakowski, E. (1987), The career dynamics of self-employment. 
Administrative Science Quarterly, 32(4), 570-589.

Carter, S. (2011), The Rewards of Entrepreneurship: Exploring the Incomes, Wealth, and Economic Well-Being of Entrepreneurial Households. Entrepreneurship: Theory and Practice, 35(1), 39-55.

Chenhall, R. H., \& Langfield-Smith, K. (2007), Multiple Perspectives of Performance Measures. European Management Journal, 25(4), 266-282.

Collins, C. J., Hanges, P. J., \& Locke, E. A. (2004), The Relationship of Achievement Motivation to Entrepreneurial Behavior: A Meta-Analysis. Human Performance, 17(1), 95-117.

Colombo, M. G., \& Grilli, L. (2005), Founders' human capital and the growth of new technology-based firms: A competence-based view. Research Policy, 34(6), 795-816.

Connor, K. M., \& Davidson, J. R. T. (2003), Development of a new Resilience scale: The Connor-Davidson Resilience scale (CD-RISC). Depression and Anxiety, 18(2), 76-82.

Creighton, .Colin, Yieke, . Felicia, Okely, .Judith, Mareri, . Lydia, Wafula, . Christopher, \& Smith, . Eunice. (2006), Understanding Gender Inequalities in Kenya; Gender inequalities in Kenya, UNESCO, Nairobi.

Cutura, J. (2006), Voices of Women Entrepreneurs in Kenya. In IFC Gender Entrepreneurship Markets \& Foreign Investment Advisory Service a joint service of the International Finance Corporation and the World Bank (p. 36). International Fiance Corporation, The World bank Group.

Day-hookoomsing, P., \& Vedna, E. (2003), Promoting Female Entrepreneurship in Mauritius: Strategies in Training and Development. International Labour Office.

De Vita, L., Mari, M., \& Poggesi, S. (2014), Women entrepreneurs in and from developing countries: Evidences from the literature. European Management Journal, 32(3), 451-460.

Delmar, F., Davidsson, P., \& Gartner, W. B. (2003), Arriving at the high-growth firm. Journal of Business Venturing, 18(2), 189-216.

Eijdenberg, E. L., Paas, L. J., \& Masurel, E. (2015), Entrepreneurial motivation and small business growth in Rwanda. Journal of Entrepreneurship in Emerging Economies, 7(3), 212-240.

El-Namaki, M. S. S. (1988), Encouraging Entrepreneurs in Developing Countries. Long Range Planning, 21(4), 98-106.

Evans, A. M., \& Revelle, W. (2008), Survey and behavioral measurements of interpersonal trust. Journal of Research in Personality, 42(6), 1585-1593.

Forest, B., \& Kali, J. (2009), Uasin gishu county Annual Development Plan 2016 2017 FY. Uasin Gishu County Government. Eldoret, Usin Gishu.

Franco, M., Haase, H., \& Pereira, A. (2016), Empirical study about the role of social networks in SME performance. Journal of Systems and Information Technology, $18(4), 383-403$.

Frank, J. (2014), Determinants of SMEs' Employment Growth Relating To The Characteristics of the Manager. Université Catholique de Louvain Institut d'Administration et de Gestion, 1-29.

Gelman, A., \& Pardoe, I. (2006), Bayesian Measures of Explained Variance and Pooling in Multilevel (Hierarchical) Models. Technometrics, 48(2), 241-251.

González-Benito, J., \& González-Benito, O. (2005), An analysis of the relationship between environmental motivations and ISO14001 certification. British Journal of Management, 16(2), 133-148.

Gulati, R., \& Kellogg, J. L. (1998), Alliances and Networks. Strategic Management Journal Strat. Mgmt. J, 19(19), 293-317. 
Gürol, Y., \& Atsan, N. (2006), Entrepreneurial characteristics amongst university students: Some insights for entrepreneurship education and training in Turkey. Education + Training, 48(1), 25-38.

Haber, S., \& Reichel, A. (2007), The cumulative nature of the entrepreneurial process: The contribution of human capital, planning and environment resources to small venture performance. Journal of Business Venturing, 22(1), 119-145.

Hans K Hvide and Jarle Møen. (2007), Discussion Paper Series 20840.

Hanson, S. (2009), Changing places through women's entrepreneurship. Economic Geography, 85(3), 245-267.

Hult, G. T. M., Hurley, R. F., \& Knight, G. A. (2004), Innovativeness: Its antecedents and impact on business performance. Industrial Marketing Management, 33(5), 429-438.

Hurley, A. E., Scandura, T. A., Schriesheim, C. A., Brannick, M. T., Seers, A., Vandenberg, R. J., \& Williams, L. J. (1997), Exploratory and confirmatory factor analysis: Guidelines, issues, and alternatives. Journal of Organizational Behavior, 18(6), 667-683.

Isaga, N. (2012), Entrepreneurship and the growth of SMEs in the furniture industry in Tanzania. Doctotal Dissertation; Vrije Universiteit Amsterdam.

Isaga, N. (2017), The relationship of personality to cognitive characteristics and SME performance in Tanzania. Journal of Small Business and Enterprise Development, 21(2), 284-300.

Isaga, N. (2018), Start-up motives and challenges facing female entrepreneurs in Tanzania. International Journal of Gender and Entrepreneurship, 2(10), 1-19.

Ishfad, A., Muhammad, M., Zafar, A., Muhammad, Z., U, A., Wasim, R., ... Ahmed, N. (2010), Determinants of Students' Entrepreneurial Career Intentions: Evidence from Business Graduates. European Journal of Social Sciences, 15(2), 14-22.

Ismail, K., Anuar, M. A., Omar, W. Z. W., Aziz, A. A., Seohod, K., \& Akhtar, C. S. (2015), Entrepreneurial Intention, Entrepreneurial Orientation of Faculty and Students towards Commercialization. Procedia - Social and Behavioral Sciences, 181(1), 349-355.

Jamali, D. (2009a), Constraints and opportunities facing women entrepreneurs in developing countries: a relational perspective. Gender in Management: An International Journal, 24(4), 232-251.

Jamali, D. (2009b), Constraints and opportunities facing women entrepreneurs in developing countries. Gender in Management: An International Journal, 24(4), $232-251$.

Jennings, J., \& McDougald, E. (2007), Work-Family Interface Experiences and Coping Strategies. The Academy of Management Review, 32(3), 747-760.

Judge, T. A., Erez, A., Bono, J. E., \& Thoresen, C. J. (2003), the Core Self-Evaluations Scale: Development of a Measure. Personnel Psychology, 56(2), 303-331.

Justo, R., DeTienne, D. R., \& Sieger, P. (2015), Failure or voluntary exit? Reassessing the female underperformance hypothesis. Journal of Business Venturing, 30(6), 775-792.

Kadir, M. B. A., Salim, M., \& Kamarudin, H. (2012), The Relationship Between Educational Support and Entrepreneurial Intentions in Malaysian Higher Learning Institution. Procedia - Social and Behavioral Sciences, 69, 21642173.

Kamil Kozan, M., Oksoy, D., \& Ozsoy, O. (2011), Owner sacrifice and small business growth. Journal of World Business, 47, 409-419.

Kenya National Bureau of Statistics. (2017a), Kenya Economic Survey 2017 (2017th ed.). Nairobi: Kenya National Bureau of Statistics.

Kenya National Bureau of Statistics. (2017b), Kenya Economic Survey 2017. 
Kiggundu, M. N. (2002), Entrepreneurs and Entrepreneurship in Africa: What is Known and What Needs to be Done. Journal of Developmental Entrepreneurship, 17(3), 239-258.

Koh, H. C. (1996), Testing hypotheses of entrepreneurial characteristics: A study of Hong Kong MBA students. Journal of Managerial Psychology, 11(3), 12-25.

Koufteros, X., Verghese, A. (John), \& Lucianetti, L. (2014), The effect of performance measurement systems on firm performance: A cross-sectional and a longitudinal study. Journal of Operations Management, 32(6), 313-336.

Krueger, N. F., Reilly, M. D., \& Carsrud, A. L. (2000), Competing models of entrepreneurial intentions. Journal of Business Venturing, 15(5-6), 411-432.

Kusyk, S. M., \& Lozano, J. M. (2007), Corporate responsibility in small and mediumsized enterprises: SME social performance: A four-cell typology of key drivers and barriers on social issues and their implications for stakeholder theory. Corporate Governance, 7(4), 502-515.

Lebakeng, M. A. (2008), An Exploration of Women Entrepreneurship in Lesotho.

Leyden, D. P., Link, A. N., \& Siegel, D. S. (2014), A theoretical analysis of the role of social networks in entrepreneurship. Research Policy, 43, 1157-1163.

Littunen, H. (2000), Entrepreneurship and the characteristics of the entrepreneurial personality. International Journal of Entrepreneurial Behaviour \& Research, 6(6), 295-310.

Lock, R., \& Lawton Smith, H. (2016), The impact of female entrepreneurship on economic growth in Kenya. International Journal of Gender and Entrepreneurship, 8(1), 90-96.

Locke, E. a., \& Latham, G. P. (2006), New directions in goal-setting theory. Current Directions in Psychological Science, 15(5), 265-268.

Maden, C. (2015), A gendered lens on entrepreneurship: Women Entrepreneurship in Turkey. Gender in Management, 30(4), 312-331.

Man, T. W., Lau, T., \& Chan, K. (2002), The competitiveness of small and medium enterprises. Journal of Business Venturing, 17(2), 123-142.

Markman, G. (2003), Beyond Social Capital: The Role of Entrepreneurs ' Social Competence in Their Financial Success competence in their financial success, 18(April), 41-60.

Markman, G. D., \& Baron, R. A. (2003), Person-entrepreneurship fit: why some people are more successful as entrepreneurs than others. Human Resource Management Review, 13(2), 281-301.

Markman, G. D., Baron, R. A., \& Balkin, D. B. (2005), Are perseverance and selfefficacy costless? Assessing entrepreneurs' regretful thinking. Journal of Organizational Behavior, 26(1), 1-19.

Masurel, E., \& Groesbeek, X. (2014), Entrepreneurial competences in a least-developed country: empirical evidence from Uganda. Unplublished Master Thesis, 1-44.

Meyer, N., \& Landsberg, J. (2015), Motivational factors influencing women's entrepreneurship: A case study of female entrepreneurship in South Africa. World Academy of Science, Engineering and Technology, International Journal of Social, Behavioral, Educational, Economic, Business and Industrial Engineering, 9(11), 3707-3712.

Mitchelmore, S., \& Rowley, J. (2010), Entrepreneurial competencies: a literature review and development agenda. International Journal of Entrepreneurial Behavior \& Research, 16(2), 92-111.

Morgan, J., \& Sisak, D. (2016), Aspiring to succeed: A model of entrepreneurship and fear of failure. Journal of Business Venturing, 31(1), 1-21.

Naguib, R., \& Jamali, D. (2015), Female entrepreneurship in the UAE: A multi-level integrative lens. Gender in Management, 30(2), 135-161. 
Nichter, S., \& Goldmark, L. (2009), Small Firm Growth in Developing Countries. World Development, 37(9), 1453-1464.

Norton, W. I., \& Moore, W. T. (2002), Entrepreneurial risk: Have we been asking the wrong question? Small Business Economics, 18(4), 281-287.

O'Grady, K. E. (1982), Measures of explained variance: Cautions and limitations. Psychological Bulletin, 92(3), 766-777.

OECD, AFDB, \& UNDP. (2017), African Economic Outlook 2017: Entrepreneurship and Industrialisation. African Economic Outlook.

Onstenk, J. (2003), Entrepreneurship and Vocational Education. European Educational Research Journal, 2(1), 74-89.

Pallant, J. (2010), SPSS survival manual:A step by step guide to data analysis using the SPSS program. McGraw Hill, New York.

Podsakoff, P. M., \& Organ, D. W. (1986), Self-Reports in Organizational Research: Problems and Prospects. Journal of Management, 12(4), 531-544.

Poon, J. M. L. (2006), Effects of Self-concept Traits and Entrepreneurial Orientation on Firm Performance. International Small Business Journal, 24(1), 61-82.

Porta, R. L. A., Lopez-de-silanes, F., Shleifer, A., \& Vishny, R. W. (1997), Legal Determinants of External Finance. The Journal of Finance, LII(3), 1131-1151.

Pouw, N., \& Elbers, C. (2012), Modelling Priority Patterns in Asset Acquisition: The Case of Smallholder Farmers in Three Rural Districts in Uganda. Journal of Development Studies, 48(9), 1360-1374.

Powell, E. E., \& Baker, T. (2011), Beyond Making Do: Toward a Theory of Entrepreneurial Resourcefulness. Frontiers of Entrepreneurship Research, 31(12), 376-388.

Rauch, A, \& Frese, M. (2000), Psychological approaches to entrepreneurial success: A general model and an overview of findings. International Review of Industrial and Organizational Psychology, 15, 101-142.

Rauch, Andreas, \& Frese, M. (2007), Let's put the person back into entrepreneurship research: A meta-analysis on the relationship between business owners' personality traits, business creation, and success. European Journal of Work and Organizational Psychology, 16(4), 353-385.

Robb, A. M., \& Watson, J. (2012), Gender differences in firm performance: Evidence from new ventures in the United States. Journal of Business Venturing, 27(5), 544-558.

Rose, R. C., Kumar, N., \& Yen, L. L. (2006), the Dynamics of Entrepreneurs ' Success Factors in Influencing. Journal of Asia Entrepreneurship and Sustainability, 11(2), 22.

Rotter, J. B. (1966), Generalized expectancies for internal versus external control of reinforcement. Psychological Monographs: General and Applied, 80(1), 1-28.

Sadler-Smith, E., Hampson, Y., Chaston, I., \& Badger, B. (2003). Managerial Behaviour, Entrepreneurial Style, And Small Firm Performance. Journal of Small Business Management, 41(1), 47-67.

Sarri, K., \& Trihopoulou, A. (2005), Female entrepreneurs' personal characteristics and motivation: a review of the Greek situation. Women in Management Review, 20(1), 24-36.

Segal, G., Borgia, D., \& Schoenfeld, J. (2000), "Entrepreneurial characteristics amongst university students: Some insights for entrepreneurship education and training in Turkey. International Journal of Entrepreneurial Behaviour \& Research, 6(3), 295-310.

Sexton, D. L., \& Bowman, N. (1985), The Entrepreneur: A Capable Executive and More. Journal of Business Venturing, Journal of(1), 129-140.

Shane, S., Locke, E. A., \& Collins, C. J. (2003), Entrepreneurial motivation. Human Resource Management Review, 13(2), 257-279. 
Shane, S., \& Venkataraman, S. (2000), The Promise of Entrepreneurship as a Field of Research. The Academy of Management Review, 25(1), 217-226.

Shenton, A. K. (2004), Strategies for ensuring trustworthiness in qualitative research projects. Education for Information, 22, 63-75.

Shepherd, D. A., Wiklund, J., \& Haynie, J. M. (2009), Moving forward: Balancing the financial and emotional costs of business failure. Journal of Business Venturing, 24(2), 134-148.

St-Arnaud, L., \& Giguère, É. (2018), Women entrepreneurs, individual and collective work-family interface strategies and emancipation. International Journal of Gender and Entrepreneurship, 10(3), 198-223.

Stephan, U., \& Pathak, S. (2016), Beyond cultural values? Cultural leadership ideals and entrepreneurship. Journal of Business Venturing, 31(5), 505-523.

Stewart, W. H., Watson, W. E., Carland, J. C., \& Carland, J. W. (1999), A proclivity for entrepreneurship. Journal of Business Venturing, 14(2), 189-214.

Sutcliffe, K. M., \& Vogus, T. J. (2003), Organizing for resilience. In Positive Organizational Scholarship: Foundations of a New Discipline (pp. 94-110).

Tajeddini, K., Elg, U., \& Trueman, M. (2013), Efficiency and effectiveness of small retailers: The role of customer and entrepreneurial orientation. Journal of Retailing and Consumer Services, 20, 453-462.

Teoh Hai Yap, \& See Liang Foo. (1997), Moderating effects of tolerance for ambiguity and risktaking propensity on the role conflict-perceived performance relationship: Evidence from singaporean entrepreneurs. Journal of Business Venturing, 12(1), 67-81.

The World Bank. (2016), Kenya-Country-Economic-Memorandum:"From Economic Growth to Jobs and Shared Prosperity". Retrieved from: http://documents.worldbank.org/curated/en/763771468197384854/pdf/103822 -WP-Kenya-Country-Economic-Memorandum-PUBLIC.pdf.

Tu, C., Hwang, S.-N., Chen, J.-S., \& Chang, F.-Y. (2012), The Joint Effects of Personal and Relationships Characteristics on Micro-Entrepreneurial Success. Procedia Economics and Finance, 4(Icsmed), 365-372.

Tumasjan, A., \& Braun, R. (2012), In the eye of the beholder: How regulatory focus and self-efficacy interact in influencing opportunity recognition. Journal of Business Venturing, 27, 622-636.

Utsch, A., \& Rauch, A. (2000), Innovativeness and initiative as mediators between achievement orientation and venture performance. European Journal of Work and Organizational Psychology, 9(1), 45-62.

Vossenberg, S. (2013), Women Entrepreneurship Promotion in Developing Countries : What explains the gender gap in entrepreneurship and how to close it? Maastricht School of Management.

Vuuren, J. Van, \& Groenewald, D. (2007), A critical analysis of the influence of startup factors in small businesses and entrepreneurial ventures in SA. Acta Commercii, 269-280.

Watson, J., \& Robinson, S. (2003), Adjusting for risk in comparing the performances of male- and female-controlled SMEs. Journal of Business Venturing, 18(6), 773-788.

Zautra, A. J., Hall, J. S., \& Murray, K. E. (2010), Resilience: A new definition of health for people and communities. Handbook of adult resilience. 
APPENDIX 1: Research Questionnaire

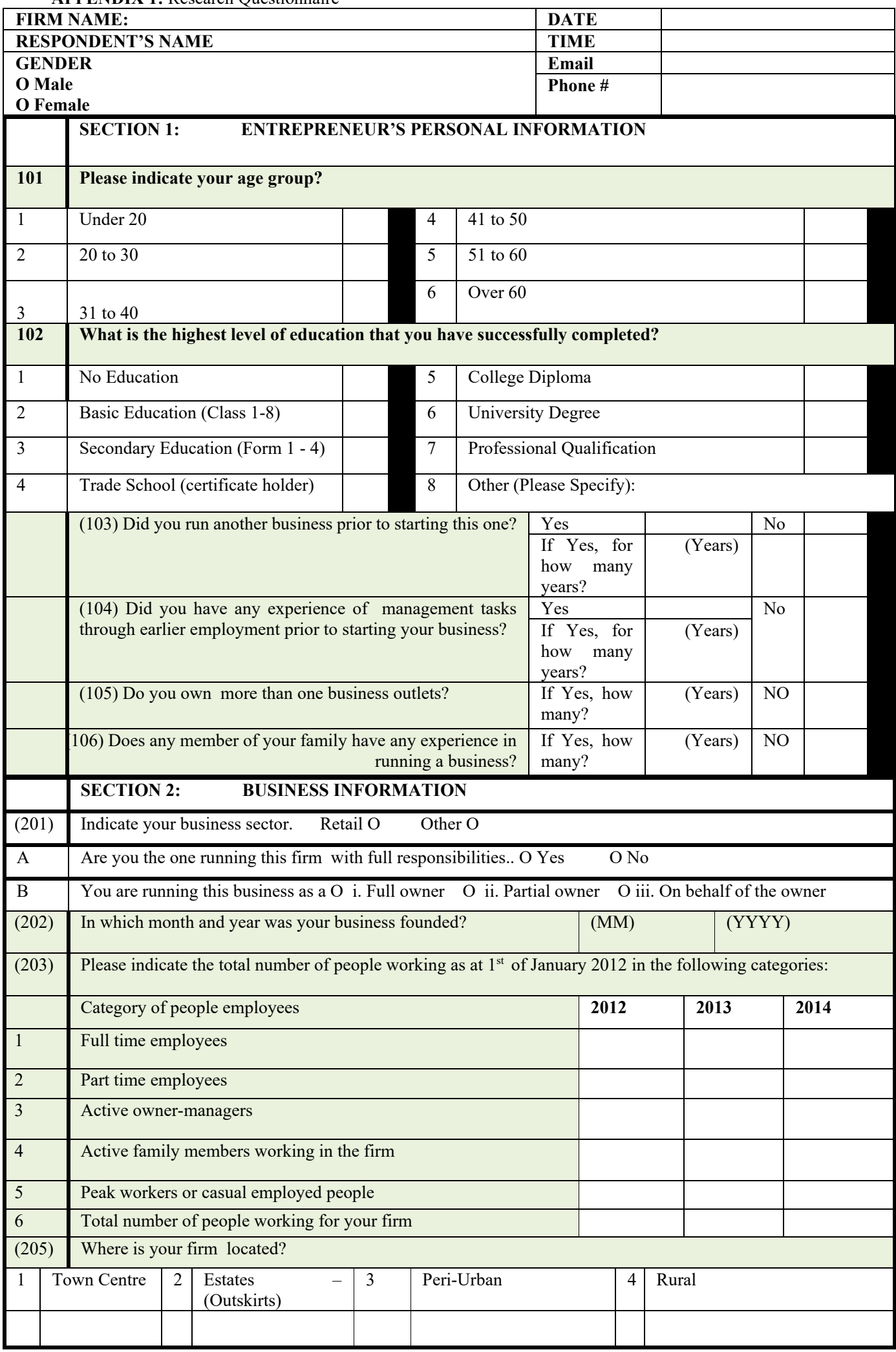




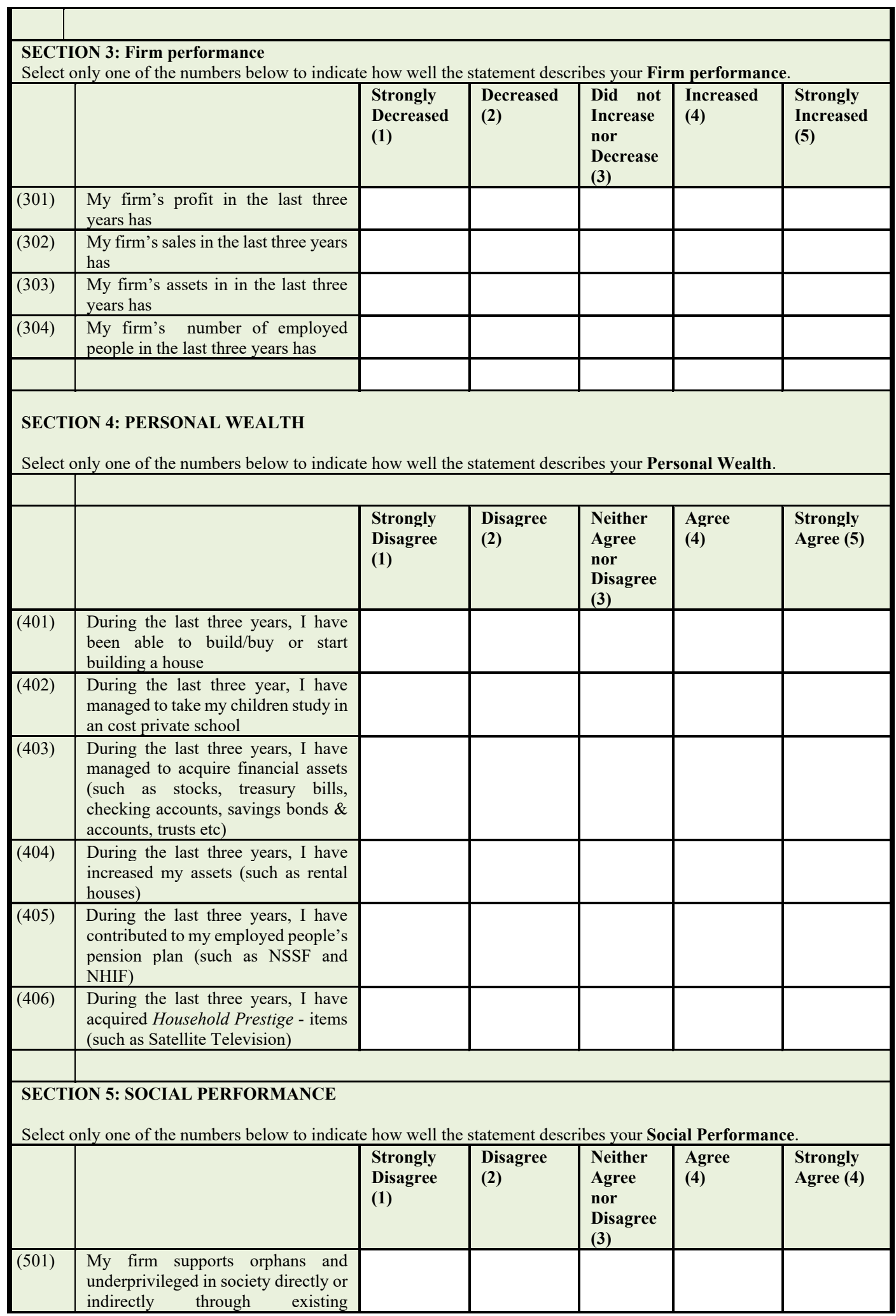




\begin{tabular}{|c|c|c|c|c|}
\hline & $\begin{array}{l}\text { institutions has increased in the last } \\
\text { three years }\end{array}$ & & & \\
\hline$(502)$ & $\begin{array}{l}\text { My firm sponsors community } \\
\text { activities such as sports, church } \\
\text { buildings, culture, traditional } \\
\text { ceremonies. }\end{array}$ & & & \\
\hline$(503)$ & $\begin{array}{l}\begin{array}{l}\text { My firm sponsors students in } \\
\text { schools. }\end{array} \\
\end{array}$ & & & \\
\hline$(504)$ & $\begin{array}{l}\text { My firm offers industrial } \\
\text { attachments, internships to students. }\end{array}$ & & & \\
\hline$(505)$ & $\begin{array}{l}\text { My firm uses a formal customers } \\
\text { complaints register for clients. }\end{array}$ & & & \\
\hline$(502)$ & $\begin{array}{l}\text { My firm improves the quality of life } \\
\text { in the communities where it operates. }\end{array}$ & & & \\
\hline$(507)$ & $\begin{array}{l}\text { My firm donates money to charities } \\
\text { in the communities where we } \\
\text { operate. }\end{array}$ & & & \\
\hline$(508)$ & $\begin{array}{l}\text { My firm makes timely payment of } \\
\text { taxes }\end{array}$ & & & \\
\hline$(509)$ & $\begin{array}{l}\text { My firm is active within an } \\
\text { organization with a social purpose. }\end{array}$ & & & \\
\hline$(510)$ & $\begin{array}{l}\text { My firm offers time and skills in } \\
\text { voluntary activities. }\end{array}$ & & & \\
\hline
\end{tabular}

SECTION 6: ENTREPRENEURIAL COMPETENCES

Please cross the box $\square$ under the number that best represents the extent to which each statement below best suits your opinion.

\begin{tabular}{|c|c|c|c|c|c|c|}
\hline & & $\begin{array}{l}\text { Strongly } \\
\text { Disagree } \\
\text { (1) }\end{array}$ & $\begin{array}{l}\text { Disagree } \\
\text { (2) }\end{array}$ & $\begin{array}{l}\text { Neither } \\
\text { Agree } \\
\text { nor } \\
\text { Disagree } \\
\text { (3) } \\
\end{array}$ & $\begin{array}{l}\text { Agree } \\
\text { (4) }\end{array}$ & $\begin{array}{l}\text { Strongly } \\
\text { Agree (5) }\end{array}$ \\
\hline (601a) & $\begin{array}{l}\text { When I fail to achieve my targets, } \\
\text { I feel very bad }\end{array}$ & & & & & \\
\hline (601b) & $\begin{array}{l}\text { I never off put important matters } \\
\text { to be done at a convenient time }\end{array}$ & & & & & \\
\hline \multirow[t]{2}{*}{$(601 c)$} & $\begin{array}{l}\text { No matter how difficult a task is, } \\
\text { I try to do as best as I can }\end{array}$ & & & & & \\
\hline & & $\begin{array}{l}\text { Strongly } \\
\text { Disagree } \\
\text { (1) }\end{array}$ & $\begin{array}{l}\text { Disagree } \\
\text { (2) }\end{array}$ & $\begin{array}{l}\text { Neither } \\
\text { Agree } \\
\text { nor } \\
\text { Disagree } \\
\text { (3) } \\
\end{array}$ & $\begin{array}{l}\text { Agree } \\
\text { (4) }\end{array}$ & $\begin{array}{l}\text { Strongly } \\
\text { Agree (5) }\end{array}$ \\
\hline$(602 a)$ & $\begin{array}{l}\text { I believe what happens in life } \\
\text { depends on what I do }\end{array}$ & & & & & \\
\hline$(602 b)$ & $\begin{array}{l}\text { I believe the outcome of many } \\
\text { tasks is determined by good or } \\
\text { bad fortune }\end{array}$ & & & & & \\
\hline \multirow[t]{2}{*}{$(602 c)$} & $\begin{array}{l}\text { I believe when I get what I want it } \\
\text { is because I was determined to } \\
\text { work hard for it }\end{array}$ & & & & & \\
\hline & & $\begin{array}{l}\text { Strongly } \\
\text { Disagree } \\
\text { (1) }\end{array}$ & $\begin{array}{l}\text { Disagree } \\
\text { (2) }\end{array}$ & $\begin{array}{l}\text { Neither } \\
\text { Agree } \\
\text { nor } \\
\text { Disagree } \\
\text { (3) } \\
\end{array}$ & $\begin{array}{l}\text { Agree } \\
\text { (4) }\end{array}$ & $\begin{array}{l}\text { Strongly } \\
\text { Agree (5) }\end{array}$ \\
\hline$(603 a)$ & $\begin{array}{l}\text { There is a right and a wrong way } \\
\text { of doing almost everything }\end{array}$ & & & & & \\
\hline$(603 b)$ & $\begin{array}{l}\text { When I am in a situation where I } \\
\text { have no control, I feel very } \\
\text { anxious }\end{array}$ & & & & & \\
\hline
\end{tabular}




\begin{tabular}{|c|c|c|c|c|c|c|}
\hline$(603 c)$ & I always see the bigger picture & & & & & \\
\hline & & $\begin{array}{l}\text { Strongly } \\
\text { Disagree } \\
\text { (1) }\end{array}$ & $\begin{array}{l}\text { Disagree } \\
\text { (2) }\end{array}$ & $\begin{array}{l}\text { Neither } \\
\text { Agree } \\
\text { nor } \\
\text { Disagree } \\
\text { (3) }\end{array}$ & $\begin{array}{l}\text { Agree } \\
\text { (4) }\end{array}$ & $\begin{array}{l}\text { Strongly } \\
\text { Agree (5) }\end{array}$ \\
\hline$(604 a)$ & I love my work & & & & & \\
\hline$(604 b)$ & $\begin{array}{l}\text { I look forward to returning to } \\
\text { work when I am away from work }\end{array}$ & & & & & \\
\hline \multirow[t]{2}{*}{$(604 c)$} & $\begin{array}{l}\text { I accomplish a lot at work because } \\
\text { I love my work }\end{array}$ & & & & & \\
\hline & & $\begin{array}{l}\text { Strongly } \\
\text { Disagree } \\
\text { (1) }\end{array}$ & $\begin{array}{l}\text { Disagree } \\
\text { (2) }\end{array}$ & $\begin{array}{l}\text { Neither } \\
\text { Agree } \\
\text { nor } \\
\text { Disagree } \\
\text { (3) } \\
\end{array}$ & $\begin{array}{l}\text { Agree } \\
\text { (4) }\end{array}$ & $\begin{array}{l}\text { Strongly } \\
\text { Agree (5) }\end{array}$ \\
\hline \multicolumn{7}{|c|}{ (605a) ork harder than most people I know } \\
\hline$(605 b)$ & $\begin{array}{l}\text { I derive most of my life } \\
\text { satisfaction from my work }\end{array}$ & & & & & \\
\hline \multirow[t]{2}{*}{$(605 c)$} & $\begin{array}{l}\text { I have never considered quitting } \\
\text { my firm regardless of the } \\
\text { problems I encounter }\end{array}$ & & & & & \\
\hline & & $\begin{array}{l}\text { Strongly } \\
\text { Disagree } \\
\text { (1) }\end{array}$ & $\begin{array}{l}\text { Disagree } \\
\text { (2) }\end{array}$ & $\begin{array}{l}\text { Neither } \\
\text { Agree } \\
\text { nor } \\
\text { Disagree } \\
\text { (3) } \\
\end{array}$ & $\begin{array}{l}\text { Agree } \\
\text { (4) }\end{array}$ & $\begin{array}{l}\text { Strongly } \\
\text { Agree (5) }\end{array}$ \\
\hline$(606 a)$ & $\begin{array}{l}\text { I like to commit myself to reach } \\
\text { particular results }\end{array}$ & & & & & \\
\hline$(606 b)$ & $\begin{array}{l}\text { I think it is important to set new } \\
\text { business targets regularly }\end{array}$ & & & & & \\
\hline \multirow[t]{2}{*}{$(606 c)$} & $\begin{array}{l}\text { I do not strive to have certain } \\
\text { number of projects in a particular } \\
\text { period }\end{array}$ & & & & & \\
\hline & & $\begin{array}{l}\text { Strongly } \\
\text { Disagree } \\
\text { (1) }\end{array}$ & $\begin{array}{l}\text { Disagree } \\
\text { (2) }\end{array}$ & $\begin{array}{l}\text { Neither } \\
\text { Agree } \\
\text { nor } \\
\text { Disagree } \\
\text { (3) }\end{array}$ & $\begin{array}{l}\text { Agree } \\
\text { (4) }\end{array}$ & $\begin{array}{l}\text { Strongly } \\
\text { Agree (5) }\end{array}$ \\
\hline$(607 a)$ & $\begin{array}{l}\text { My life is mainly determined by } \\
\text { my own actions }\end{array}$ & & & & & \\
\hline$(607 b)$ & $\begin{array}{l}\text { When I get what I want its mainly } \\
\text { because I worked for it }\end{array}$ & & & & & \\
\hline \multirow[t]{2}{*}{$(607 c)$} & $\begin{array}{l}\text { When I set important goals for } \\
\text { myself, I do not always achieve } \\
\text { them }\end{array}$ & & & & & \\
\hline & & $\begin{array}{l}\text { Strongly } \\
\text { Disagree } \\
\text { (1) }\end{array}$ & $\begin{array}{l}\text { Disagree } \\
\text { (2) }\end{array}$ & $\begin{array}{l}\text { Neither } \\
\text { Agree } \\
\text { nor } \\
\text { Disagree } \\
\text { (3) } \\
\end{array}$ & $\begin{array}{l}\text { Agree } \\
\text { (4) }\end{array}$ & $\begin{array}{l}\text { Strongly } \\
\text { Agree (5) }\end{array}$ \\
\hline$(608 \mathrm{a})$ & $\begin{array}{l}\text { The term 'risk taker' is considered } \\
\text { a positive attribute for people in } \\
\text { our firm }\end{array}$ & & & & & \\
\hline$(608 b)$ & $\begin{array}{l}\text { People in our firm are encouraged } \\
\text { to take calculated risks with new } \\
\text { ideas }\end{array}$ & & & & & \\
\hline$(608 \mathrm{c})$ & $\begin{array}{l}\text { Our firm emphasizes both } \\
\text { exploration and experimentation } \\
\text { for opportunities }\end{array}$ & & & & & \\
\hline
\end{tabular}




\begin{tabular}{|c|c|c|c|c|c|c|}
\hline & & $\begin{array}{l}\text { Strongly } \\
\text { Disagree } \\
\text { (1) }\end{array}$ & $\begin{array}{l}\text { Disagree } \\
\text { (2) }\end{array}$ & $\begin{array}{l}\text { Neither } \\
\text { Agree } \\
\text { nor } \\
\text { Disagree } \\
\text { (3) }\end{array}$ & $\begin{array}{l}\text { Agree } \\
\text { (4) }\end{array}$ & $\begin{array}{l}\text { Strongly } \\
\text { Agree (5) }\end{array}$ \\
\hline$(609 a)$ & $\begin{array}{l}\text { My firm actively introduces } \\
\text { improvements and innovations in } \\
\text { our business }\end{array}$ & & & & & \\
\hline$(609 b)$ & $\begin{array}{l}\text { My firm seeks out new ways of } \\
\text { doing business }\end{array}$ & & & & & \\
\hline \multirow[t]{2}{*}{$(609 \mathrm{c})$} & $\begin{array}{l}\text { My firm is creative in its methods } \\
\text { of operation }\end{array}$ & & & & & \\
\hline & & $\begin{array}{l}\text { Strongly } \\
\text { Disagree } \\
\text { (1) }\end{array}$ & $\begin{array}{l}\text { Disagree } \\
\text { (2) }\end{array}$ & $\begin{array}{l}\text { Neither } \\
\text { Agree } \\
\text { nor } \\
\text { Disagree } \\
\text { (3) } \\
\end{array}$ & $\begin{array}{l}\text { Agree } \\
\text { (4) }\end{array}$ & $\begin{array}{l}\text { Strongly } \\
\text { Agree (5) }\end{array}$ \\
\hline$(610 \mathrm{a})$ & ding an office job does not take long & & & & & \\
\hline$(610 \mathrm{~b})$ & pect a quick return on my investment & & & & & \\
\hline \multirow[t]{4}{*}{$(610 \mathrm{c})$} & $\begin{array}{l}\text { I could go without a profit for at } \\
\text { least six months }\end{array}$ & & & & & \\
\hline & & $\begin{array}{l}\text { Strongly } \\
\text { Disagree } \\
\text { (1) }\end{array}$ & $\begin{array}{l}\text { Disagree } \\
\text { (2) }\end{array}$ & $\begin{array}{l}\text { Neither } \\
\text { Agree } \\
\text { nor } \\
\text { Disagree } \\
\text { (3) }\end{array}$ & $\begin{array}{l}\text { Agree } \\
\text { (4) }\end{array}$ & $\begin{array}{l}\text { Strongly } \\
\text { Agree (5) }\end{array}$ \\
\hline & $\begin{array}{l}\text { I am confident I get the success I } \\
\text { deserve in life }\end{array}$ & & & & & \\
\hline & Sometimes I feel depressed & & & & & \\
\hline \multirow[t]{4}{*}{ (611c) } & $\begin{array}{l}\text { I am capable of coping with most } \\
\text { of my problems }\end{array}$ & & & & & \\
\hline & & $\begin{array}{l}\text { Strongly in } \\
\text { accurate } \\
\text { (1) }\end{array}$ & $\begin{array}{l}\text { inaccurate } \\
\text { (2) }\end{array}$ & $\begin{array}{l}\text { Neither } \\
\text { Accurate } \\
\text { nor } \\
\text { inaccura } \\
\text { te (3) } \\
\end{array}$ & $\begin{array}{l}\text { Accurate } \\
\text { (4) }\end{array}$ & $\begin{array}{l}\text { Strongly } \\
\text { Accurate } \\
\text { (5) }\end{array}$ \\
\hline & I anticipate the needs for others & & & & & \\
\hline & $\begin{array}{l}\text { I believe that laws should be } \\
\text { strictly enforced }\end{array}$ & & & & & \\
\hline$(612 c)$ & $\begin{array}{l}\text { I believe that laws should be } \\
\text { strictly followed }\end{array}$ & & & & & \\
\hline
\end{tabular}

